\title{
microRNA: The Impact on Cancer Stemness and Therapeutic Resistance
}

\author{
Xueqiao Jiao $^{+} \mathbb{D}$, Xianling Qian ${ }^{+} \mathbb{D}$, Longyuan Wu ${ }^{\mathbb{D}}$, Bo Li ${ }^{\mathbb{D}}$, Yi Wang, Xinyu Kong and \\ Lixia Xiong * (D)
}

Jiangxi Province Key Laboratory of Tumor Pathogenesis and Molecular Pathology, Department of Pathophysiology, Medical College, Nanchang University, 461 Bayi Road, Nanchang 330006, China; jiaoxueqiao1550@163.com (X.J.); 6302615051@email.ncu.edu.cn (X.Q.); wulongyuan1201@163.com (L.W.); libo181818@126.com (B.L.); 401442719031@email.ncu.edu.cn (Y.W.); xinyu.kong@se17.qmul.ac.uk (X.K.)

* Correspondence: xionglixia@ncu.edu.cn; Tel.: +86-791-8636-0556

+ These authors contributed equally to this work.

Received: 16 October 2019; Accepted: 16 December 2019; Published: 18 December 2019

\begin{abstract}
Cancer ranks as the second leading cause of death worldwide, causing a large social and economic burden. However, most anti-cancer treatments face the problems of tumor recurrence and metastasis. Therefore, finding an effective cure for cancer needs to be solved urgently. Recently, the discovery of cancer stem cells (CSCs) provides a new orientation for cancer research and therapy. CSCs share main characteristics with stem cells and are able to generate an entire tumor. Besides, CSCs usually escape from current anti-cancer therapies, which is partly responsible for tumor recurrence and poor prognosis. microRNAs (miRNAs) belong to small noncoding RNA and regulate gene post-transcriptional expression. The dysregulation of miRNAs leads to plenty of diseases, including cancer. The aberrant miRNA expression in CSCs enhances stemness maintenance. In this review, we summarize the role of miRNAs on CSCs in the eight most common cancers, hoping to bridge the research of miRNAs and CSCs with clinical applications. We found that miRNAs can act as tumor promoter or suppressor. The dysregulation of miRNAs enhances cell stemness and contributes to tumor metastasis and therapeutic resistance via the formation of feedback loops and constitutive activation of carcinogenic signaling pathways. More importantly, some miRNAs may be potential targets for diagnosis, prognosis, and cancer treatments.
\end{abstract}

Keywords: microRNA; cancer; cancer stem cell; therapeutic resistance; cancer therapy

\section{Introduction}

Cancer is a neoplasm characterized by uncontrolled cell growth and the ability of invasion. It was estimated that in 2018, there were 18.1 million new cancer cases and 9.6 million cancer deaths around the whole word [1]. According to the World Health Organization (WHO), cancer is the second leading cause of death globally, just after cardiovascular diseases [2]. Despite the tremendous effects made in developing first-line anti-cancer drugs, resection surgery, combinational chemotherapy, and radiotherapy, many patients still face high rates of tumor recurrence and metastasis. Currently, most anti-cancer drugs, as well as conventional chemotherapy, mainly target proliferative cancer cells called non-cancer stem cells while the quiescent cancer cells, named cancer stem cells (CSCs), survive [3]. The aggressive characteristics of cancer, such as recurrence, metastasis, and drug resistance, are partially due to the CSCs population [4].

CSCs are pluri- or multi-potent cancer cells, which behave like stem cells in producing heterogeneous cancer cells and have the ability to self-renew [5]. The characteristics of CSCs are known as "cancer stemness" as well, promoting growth of the primary tumor and metastasis of the secondary 
tumor [6]. CSCs were firstly discovered in the 1890s during an experiment comparing the similarities of tumor tissues with embryonic tissues [6]. It has been proven that a single tumor cell of mice is able to develop into a new tumor in the recipient mouse. During the late 1990s, studies have shown in acute myeloid leukemia cell transplantation that only cells expressing $\mathrm{CD} 34^{+} \mathrm{CD} 38^{-}$form the entire tumor, which are the CSCs of leukemia [7]. Moreover, CSCs were observed to only occupy one per million leukemia tumor cells, indicating that CSCs were identified in leukemia both qualitatively and quantitatively [8]. Then, CSCs were found in a variety of hematopoietic cancers or solid tumors, such as breast, colon, brain, liver, and stomach. Nowadays, it is widely accepted that CSCs are products of combinational genetic and epigenetic changes in normal stem cells. [9]. Besides the stem cell-like properties of proliferation and self-renewal, CSCs have other crucial characteristics as well (Figure 1). Firstly, during CSCs' proliferation, CSCs form a three-dimensional sphere which is called the tumorsphere. In vitro, the tumorsphere formation assay is widely used for CSCs' isolation and identification [10]. Secondly, a few CSCs are enough to form an entire tumor [11], as CSCs only account for $1 \%$ of all tumor cells and produce heterogeneous tumor cells to form the tumor mass [6]. Thirdly, CSCs in the recipient after transplantation are still able to be transplanted to the next recipient [11]. Fourthly, CSCs are resistant to conventional chemotherapy and radiotherapy [12], which mainly target more mature tumor cells [4], resulting in the enrichment of CSCs in the tumor. The fraction of CSCs positively correlates with tumor progression, metastasis, recurrence, and poor prognosis [13]. Fifthly, CSCs possess distinctive surface membrane markers, which are helpful in CSCs' identification and isolation [14]. Those markers are proteins on CSCs' cell membrane, many of which are receptors or antigens. The kinds of CSC markers varies in different tumors; CD24, CD44, and CD133 are three main CSC markers for the most malignant tumors [15]. Due to the ongoing studies and acknowledgement of CSCs' properties, the significance of developing CSC-targeted cancer therapies in the case of recurrence and metastasis cannot be underestimated.

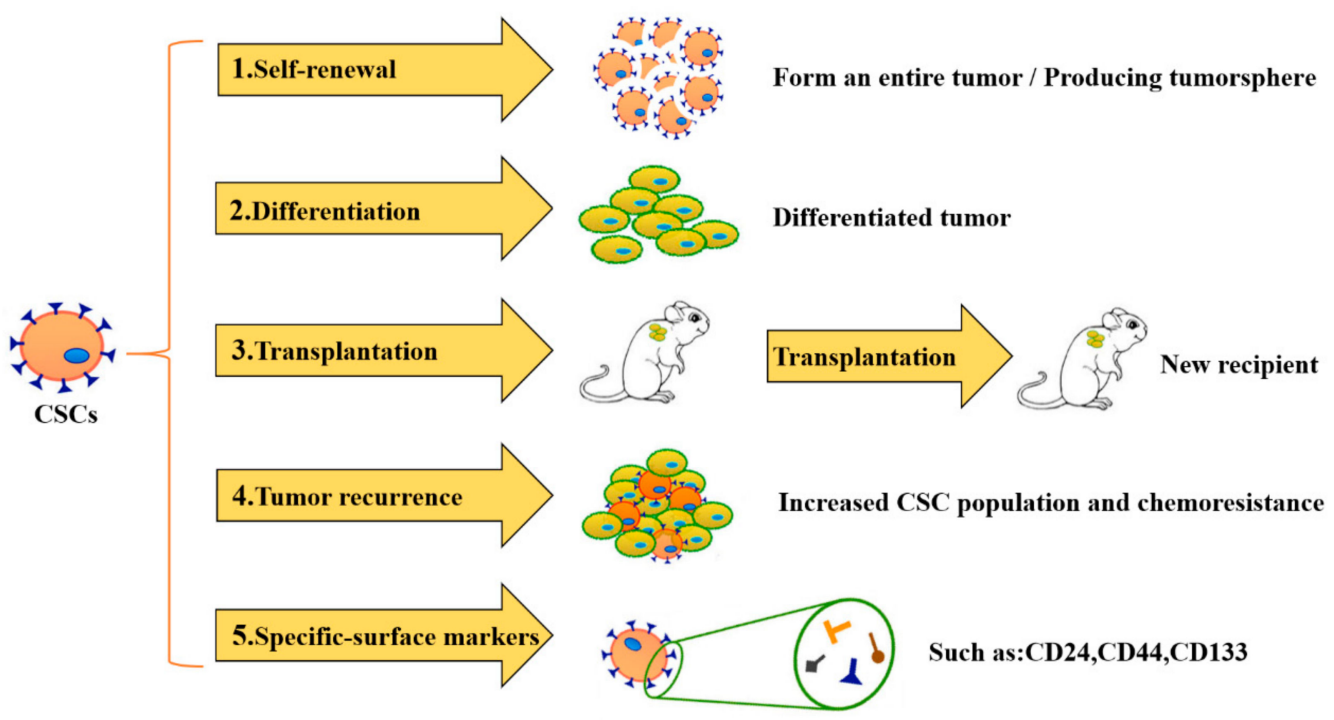

Figure 1. The characteristics of cancer stem cells (CSCs). CSCs have five specific characteristics, which are used for identifying and evaluating cancer stemness. 1. CSCs are able to self-renew and form a tumorsphere. 2. A few CSCs are able to form an entire tumor. 3. CSCs in the recipient can be transplanted to the next recipient. 4. CSCs are responsible for tumor recurrence and chemoresistance. 5. CSCs have many specific stem markers on the cell membrane.

One of the CSC-targeted therapies eliminates CSCs by targeting related microRNA (miRNA) [16]. miRNAs are about 20- to22-long nucleotides, which belong to the small non-coding RNA family [17]. miRNAs regulate gene expression post-transcriptionally via RNA interference and their levels are inversely associated with the expression of their downstream targets. After cleavage, miRNAs bind to the $3^{\prime}$ untranslated region (3'-UTR) of targeting mRNA, resulting in mRNA silencing [18]. Considering 
that miRNAs can control multiple gene expressions and the abundance of miRNAs in cells, it is not surprising to find that miRNAs play a role in crucial cell activities, such as cell proliferation, metabolism, and apoptosis. Over $60 \%$ of the genes in mammals are regulated by different miRNAs [19]. Most miRNAs are highly evolutionarily conserved, suggesting that miRNAs may be involved in basic biological functions [20]. Abnormal miRNA expression may lead to severe diseases, such as cancer. Studies have shown that abnormal miRNA expression contributes to cancer development in several different ways. miRNAs can be divided into tumor-suppressor and -promoter miRNAs depending on what they regulate and where they are expressed [21]. In recent years, plenty of studies have proven that overexpression or downregulation of various miRNAs in cancers might regulate CSC proliferation and metastasis to facilitate cancer development. In this review, we mainly focus on the relationship between miRNAs and CSCs in the eight most common cancers, hoping to cast new light on miRNA-targeting therapy.

\section{Lung Cancer}

According to histopathological diagnosis, lung cancer can be divided into two main categories. One is small cell lung cancer, accounting for about $15 \%$ of lung cancers. The other is non-small cell lung cancer (NSCLC), accounting for about $85 \%$ of lung cancers [22]. Except for the conventional therapies, such as anti-tumor drug, chemotherapy, and radiotherapy, accumulating research of lung cancer stem cells has demonstrated that CSC therapy for lung cancer would provide more effective treatment for lung cancer patients.

\section{1. $m i R-122$}

Studies have reported that miR-122 plays a tumor suppressor role by inhibiting the expression of several oncogenes [23,24]. In NSCLC, miR-122 also acts as a tumor suppressor to suppress CSCs in the A549, H460, HCC827 cell line. The induced expression of miR-122 suppresses CSC proliferation by inducing apoptosis, decreasing the stem markers' expression, as well as sensitizing CSCs to chemotherapy and radiotherapy. miR-122 inhibits the stemness characteristics in NSCLC by binding to peroxiredoxin II (Prx II) mRNA and suppressing its translation. Then, miR-122 improves reactive oxygen species (ROS) intracellular levels to induce apoptosis.

Peroxiredoxins (Prxs) is a superfamily of an ubiquitous cysteine-based anti-oxidant family, and Prxs II is one of the six isoforms of Prx in humans [25]. Prx II contributes to an anti-oxidant effect when it is expressed intracellularly, and has an important function for mediating inflammation when it is expressed extracellularly [26]. Prxs are aberrantly upregulated in several cancers, which has a crucial influence on promoting tumor progression [27].

As the downstream signaling pathway of Prx II, sonic hedgehog (SHH), gil family zinc finger 1 (gli-1) of the Hedgehog pathway, notch receptor 1 (Notch1), hes family bHLH transcription factor 1 (Hes-1) of the Notch pathway, and $\beta$-catenin expression are all downregulated after miR-122 induction [28].

\section{2. $m i R-128$}

In lung cancer, miR-128 is identified as a tumor suppressor in A549/paclitaxel (PTX) cell lines. miR-128 inhibits CSC self-renewal, reduces CSC markers expression, and increases the sensitivity to PTX.

The B-cell-specific Moloney murine leukemia virus insertion site 1 (BMI-1) is a proto-oncogene that belongs to the polycomb protein family [29]. BMI-1 plays a role in tumor metastasis through promoting oncogenic transformation and regulating epithelial-mesenchymal transition (EMT) [30]. Therefore, the overexpression of BMI-1 in lung carcinoma indicates aggressive tumor progression and poor prognosis. Mucin 1-C (MUC1-C) is the transmembrane subunit of MUC1 [31]. MUC1-C interacts with tyrosine kinase receptor (TRK), which subsequently activates the MAP kinse-ERK kinase (MEK)/extracellular regulated MAP kinase (ERK) and phosphatidylinositol 3-kinase (PI3K)/AKT serine/threonine kinase 1 
(Akt) signaling pathway. MUC1 overexpression is detected in over $80 \%$ of NSCLCs, and has a crucial effect on maintaining cancer stemness and clonogenicity [31].

miR-128 suppresses BMI-1 and MUC1 expression to reduce stemness protein production and suppresses CSC characteristics in A549/PTX cell lines. Due to the suppression of MUC1-C and BMI-1, the MEK/ERK, PI3K/Akt and Wingless (Wnt)/ $\beta$-catenin pathways are downregulated, leading to a decrease of the CSC population and impaired chemoresistance to PTX. In short, miR-128 is one of the potential targets for lung cancer treatment [32].

\section{3. $m i R-19$}

In lung cancer, miR-19 facilitates tumor metastasis by triggering EMT [33]. Moreover, miR-19 promotes tumorsphere formation and increases the expression of stem markers in the A549 and H1299 cell lines of lung cancer.

miR-19 is overexpressed in lung CSCs and it directly suppresses glycogen synthase kinase $3 \beta$ $($ GSK3 $\beta)$, which is one of the negative regulators of the $\mathrm{Wnt} / \beta$-catenin pathway. Therefore, the $\mathrm{Wnt} / \beta$-catenin pathway is continuously activated in CSCs under the overexpression of miR-19. In short, study of miR-19 may provide new insights for lung cancer treatments [10].

\section{4. $m i R-410$}

In NSCLC, miR-410 acts as an oncogenic miRNA and contributes to tumorigenesis. miR-410 facilitates the rate of tumorsphere formation, promotes the expression of stem markers and cell growth, as well as increasing cell resistance to cisplatin in A549 and H1299 cell lines.

miR-410 directly interferes with GSK3 $\beta$ expression. Consequently, the canonical Wnt pathway is hyperactivated in CSCs of NSCLC, which is positively associated with CSC generation maintenance [34-36]. In conclusion, miR-410 promotes tumor development and metastasis and enhances stemness via activation of the Wnt/ $\beta$-catenin pathway [37].

\section{5. $m i R-30$}

miR-30 plays a role as tumor suppressor in the CSCs of NSCLC. Studies show that in the SPC-A1 and NCI-H1650 cell line of NSCLC, miR-30 suppresses tumorsphere formation, inhibits cell growth, and induces cell apoptosis by inhibiting transmembrane-4 L-six family member-1 (TM4SF1).

TM4SF1, a glycoprotein on the plasma membrane, contributes to cell growth and motility [38]. TM4SF1 binds to discoidin domain receptor 1 (DDR1) [39], which is involved in positively regulating the activation of the PI3K/Akt pathway. Due to the downregulation of miR-30, the overexpression of TM4SF1 in CSCs promotes tumorsphere formation and the proliferation of CSCs. In other words, miR-30 interferes with CSC development and induces cell apoptosis [40].

\section{6. $m i R-127$}

miR-127 is vital for lung formation and stem cell differentiation in the embryonic period [41,42]. Overexpression of miR-127 in lung cancer is positively associated with poor prognosis and tumor recurrence. In PC9 and A549 cell lines, oncogenic miR-127 promotes stemness by enhancing self-renewal ability, increasing the expression of stem markers, promoting tumorsphere formation, and increasing cell resistance to gemcitabine via the targeting of tumor necrosis factor alpha-induced 3 (TNFAIP3).

TNFAIP3 is a ubiquitin enzyme, which acts as a negative effector to switch nuclear factor kappa $B$ subunit 1 (NF- $\mathrm{kB}$ ) signaling off. The overexpression of miR-127 suppresses TNFAIP3 expression, leading to NF- $\mathrm{KB}$ pathway activation. The overexpression NF- $\mathrm{KB}$ in lung cancer cells, especially CSCs, contributes to cell proliferation, metastasis, and inhibition of apoptosis [43]. Moreover, the upregulation of NF- $\mathrm{kB}$ in turn increases miR-127 expression. As a result, miR-127, NF- $\mathrm{kB}$, and TNFAIP3 form a feedforward loop in lung cancer to regulate cell stemness, which promotes CSCs' self-renewal and accelerates tumorigenesis [44]. 
The miR-127-mediated positive feedback loop plays a crucial role in tumor aggressiveness, metastasis, and stemness maintenance. Through sustainable self-reinforcing, CSCs enhance the characteristics and enlarge the population.

\section{7. $m i R-129-5 p$}

The downregulation of miR-129-5p is involved in many kinds of tumor development, such as glioblastoma multiforme [45]. In NSCLC cell lines A549 and H460, miR-129-5p reduces CSC markers' expression, self-renewal ability, and chemoresistance through inhibition of delta-like 1 homolog (DLK1).

DLK1 positively correlates with tumor invasion ability [46]. DLK1 overexpression positively correlates with CSC stemness. By targeting and inhibiting DLK1 expression, miR-129-5p impairs CSCs' characteristics [47]. The relationship between miR-129-5p and DLK1 helps to reveal the mechanism of the Notch signaling pathway in CSCs.

\section{8. $m i R-181 b$}

As a tumor suppressor, miR-181b is downregulated in NSCLC cell lines H1650, H1299, and A549. Additionally, the expression of miR-181b in CSCs decreases stem markers' expression, suppresses tumorsphere formation, and increases chemosensitivity.

miR-181b is negative regulator of notch receptor 2 (Notch2), which works as an important protein in stem cells. Notch2 is highly expressed in CSCs, promoting the increase of stem markers and the transcription of stem genes. By inhibiting Notch2 translation, miR-181b inhibits stemness characteristics [48].

\section{Breast Cancer}

Breast cancer $(\mathrm{BC})$ is one of the most prevalent cancers worldwide, which seriously threatens female health. In 2018, 20.9 million new cases of breast cancer were diagnosed and 6.3 million people died from cancer [1]. Triple-negative breast cancer (TNBC) is the most aggressive breast cancer, with a higher percentage of CSCs [49]. Plenty of studies shown that some miRNAs, such as miR-34a, miR-33b, miR-137, and miR-873, act as tumor suppressors in breast CSCs while other miRNAs, such as miR-221, are overexpressed and act as an oncogene in breast CSCs.

\section{1. $m i R-34 a$}

miR-34a targets several different mRNAs to affect breast cancer stemness as a tumor suppressor. The induced overexpression of miR-34a could eliminate some CSCs in breast cancer. miR-34a suppresses tumorshphere formation, CSCs' self-renewal ability, the expression of stem markers, and drug resistance in the MCF-7 breast cancer cell line by inhibiting serine/threonine-protein kinase D1 (PRKD1).

PRKD1 overexpression helps to maintain cancer stemness through phosphorylation of protein kinase $\mathrm{D} /$ protein kinase $\mathrm{C}(\mathrm{PKD} / \mathrm{PKC} \mu)$ and activation of the $\mathrm{Wnt} / \beta$-catenin pathway [50]. Additionally, phosphorylated PKD/PKC $\mu$ has a negative effect on apoptosis through caspase-3 inhibition [51]. As a result, both the number and the self-renewal ability of CSCs are increased. miR-34a-mediated suppression of PRKD1 not only leads to the reduction of stemness and the suppression of tumor growth but also initiates apoptosis, with reduced drug resistance [52].

However, the specific mechanism of PRKD1 remains unknown [50], and some research also indicates that PRKD1 has a contrary effect as a tumor suppressor or promoter in different cancer types [53]. For example, PRKD1 is expressed in normal ductal epithelial cells of the breast and inhibits EMT, which is a vital step for tumor cells to acquire the ability of invasion and metastasis [54]. Therefore, the PRKD1 promoter is silenced in invasive breast cancer cells, leading to low expression of PRKD1, which contributes to tumor invasion and metastasis [55]. The discovery of the miR-34a/PRKD1 mechanism may contribute to the investigation of breast cancer and its CSCs on the molecular level. 
Moreover, in the MCF-7 human breast cancer cell line, miR-34a inhibits CSCs' self-renewal ability, cell proliferation, tumorsphere formation, and the expression of stem markers by suppressing sirtuin 1 (SIRT1) expression.

SIRT1, a nicotinamide adenine dinucleotide-dependent histone deacetylase, plays crucial roles in gene silencing, cell cycle arrest, and apoptosis [56], and it is also involved in maintaining pluripotent stem cells' generation [57]. In normal conditions, p53, miR-34a, and SIRT1 form a feedback loop to regulate cell apoptosis. p53 expression upregulates miR-34a expression, and miR-34a directly suppresses SIRT1 translation, downregulating SIRT1. SIRT1's low expression stimulates the acetylation and subsequent activity of p53, which induces cell apoptosis and increases CSCs' survival rate [58].

In breast CSCs, SIRT1 is upregulated while miR-34a is downregulated, leading to an increase of the self-renewal ability of breast CSCs, and the CSC population by suppressing p53-dependent apoptosis [59]. Therefore, by targeting and disturbing the miR-34a-SIRT1 axis in breast CSCs, tumorigenesis could be effectively inhibited, with a lower rate of cancer recurrence and death.

In addition, in the MCF-7 cell line, miR-34a also decreases CSC stem markers' expression, suppresses tumorsphere formation, and increases sensitivity to PTX through negatively regulation of Notch1 expression. Notch and its downstream signaling are both involved in the self-renewal and differentiation of breast CSCs [60]. Compared to non-CSCs of breast cancer, CSCs has lower miR-34a expression and higher Notch1 mRNA expression. Both inducing miR-34a and suppressing Notch1 mRNA expression in CSCs would not only lead to the shrinkage of the CSC population and suppressed stemness but also make the tumor mass more sensitive to chemotherapy [61].

\section{2. $m i R-185-3 p$}

As a tumor suppressor, the low expression of miR-185-3p in breast cancer always indicates poor prognosis. In the human breast cell line, MDA-MB-468, MDA-MB-231, MDA-MB-453, and MCF-7, miR-185-3p decrease CSC stem markers' expression, inhibiting cell proliferation, and reducing the quantity and quality of tumorsphere formation.

miR-185-3p directly suppresses E2F transcription factor 1 (E2F1), which is overexpressed in breast CSCs. E2F1 acts as Nanog promoter by enhancing Nanog expression. E2F1 and Nanog overexpression is crucial for CSC properties' maintenance and tumorigenesis [62]. Therefore, the miR-185-3p/E2F1/Nanog axis is also worthy of studying in miRNA-targeting therapy for breast cancer.

\section{3. $m i R-590-5 p$}

miR-590-5p expression is negatively associated with CSCs' development in the MCF-7 and ZR75-1 cell line. Through inhibition of sex determining region $\mathrm{Y}$ (SRY)-box transcription factor 2 (SOX2), $\mathrm{miR}-590-5 \mathrm{p}$ decreases stem marker expression and tumorsphere formation.

SOX2 is a transcription factor (TF), which is abnormally overexpressed in breast CSCs, and responsible for CSCs' generation and maintenance [63]. SOX2 is vital for embryonic stem cell (ESC) development [64], and its overexpression in breast CSCs contributes to pluripotency maintenance. The abnormal expression of SOX2 in cancers always indicates a higher grade of tumors.

miR-590-5p directly suppresses SOX2 expression in breast cancer cells. Induced miR-590-5p expression not only decreases the amount of CSCs by through inhibiting SOX2 but also inhibits tumorigenesis significantly [65]. Therefore, by upregulating the expression of miR-590-5p, SOX2 expression is suppressed and tumorigenesis is effectively inhibited.

\section{4. $m i R-33 b$}

In the human breast cancer cell lines MCF-7, MDA-MB-231, BT-549, MDA-MB-453, SK-BR-3, and $4 \mathrm{~T} 1$, miR-33b acts as a tumor suppressor to inhibit CSC properties, such as tumorsphere formation, the expression of stem markers, and self-renewal ability, by inhibiting the high-mobility group AT-hook 2 (HMGA2), spalt-like transcription factor 4 (SALL4), and twist family bHLH transcription factor 1 (Twist1). 
HMGA2, SALL4, and Twist1 are overexpressed in breast cancer, facilitating the self-renewal of CSCs, and enlarging the population of CSCs, leading to the tumor acquiring a higher invasive and metastatic ability [66]. However, it is noticeable that in hematopoietic stem cells, miR-33 can suppress p53 directly to promote stem cells' self-renewal and inhibit cell apoptosis [67]. Therefore, due to the different effects of miR-33b in CSCs and HSCs, further investigation is warranted for assessing the feasibility of BC therapy by targeting this miRNA.

\section{5. $m i R-137$}

miR-137 inhibits CSC stem markers' expression, tumorsphere formation, and metastasis in the TNBC cell line MDA-MB-231 and SUM149. miR-137 acts as a tumor suppressor by suppressing B-cell lymphoma/leukemia 11A (BCL11A) expression, leading to the inhibition of CSCs' self-renewal and proliferation ability, and shrinkage of the tumor mass.

BCL11A is an oncoprotein, which is highly expressed in breast cancer and involved in maintaining the CSC population. BCLL11A interacts with DNA methyltransferases 1 (DNMT1), which also contributes to CSCs' maintenance in various cancers, including breast cancer [68]. miR-137 also disturbs the BCL11A-DNMT1 interaction by suppressing BCL11A expression at both the mRNA and protein level [69]. As a result, TNBC development and cancer stemness are impaired. Considering the high chemoresistance and poor prognosis of TNBC patients, using miR-137 to limit the CSC population and inhibit tumorigenesis is quite promising.

\section{6. $m i R-873$}

miR-873 is a tumor suppressor of breast cancer. In the cell lines MCF-7 and MDA-MB-231, miR-873 is able to reduce the expression of stem markers and pluripotent transcription factors, suppress tumorsphere formation, and lower CSCs' chemoresistance by inhibiting programmed cell death ligand 1 (PD-L1).

PD-L1 is an immune checkpoint that is always found as being overexpressed in solid tumors [70]. The higher the expression of PD-L1 in breast cancer, the stronger the cancer stemness is. PD-L1 could propagate the CSC population by continuous hyperactivation of the PI3K/Akt and mitogen activated protein kinase (MAPK)/ERK pathways.

miR-873 attenuated both the stemness and chemoresistance of $B C$ cells via direct targeting of PD-L1, thus inactivating downstream PI3K/Akt and ERK1/2 signaling. It is notable that compared with the results of Akt/ERK1/2 inhibitors, the results of miR-873/PD-L1 in decreasing the cancer stemness are much more effective, indicating that there must be other pathways involved in the miR-873/PD-L1 axis for CSC generation [71].

\section{7. $m i R-221$}

miR-221 acts as a cancer promoter that is overexpressed in breast cancer cells. In the breast cancer cell line T47D, the upregulation of miR-221 promotes tumorsphere formation and the expression of stem markers. miR-221 enhances CSC properties by directly suppressing the expression of DNA methyltransferase $3 b$ (DNMT3b), which could inhibit the expression of stemness genes, such as Oct3/4 and Nanog, by methylating their promoters [72]. miR-221 directly inhibits DNMT3b expression, leading to the overexpression of those stemness genes in CSCs. Therefore, miR-221 overexpression in breast cancer cells usually contributes to an increase of the CSC population and higher probability of recurrence and metastasis [73]. Notably, DNMT3b plays dual roles in different kinds or stages of cancers. Classically, DNMT 3b is recognized as an oncoprotein [74] while in higher tumor stages, it was found that it could act as a tumor suppressor [75]. Thus, whether DNMT3b acts as a tumor suppressor or promoter may depend on the tumor stage and specific tumor type. 


\section{Colorectal Cancer}

Colorectal cancer (CRC) is the third most common cancer and the second leading cause of cancer mortality next to lung cancer [1]. Although great progress has been made in CRC clinical therapy, problems, such as chemoresistance and subsequent recurrence, are intractable and need to be settled urgently. CRC is a heterogeneous malignant tumor as well, and as we mentioned before, focusing on the regulatory effect of miRNAs on CSCs may be a potential strategy to solve those problems in CRC treatment.

\section{1. $m i R-148 a$}

Low expression of miR-148a in CRCs (e.g., the SW480 cell line) is usually associated with distant metastasis, recurrence, and poor tumor differentiation. As a tumor suppressor, miR-148a not only inhibits stem markers' expression and tumorsphere formation and reduces drug resistance but also induces apoptosis.

In CSCs, miR-148a suppresses Wnt family member 10b (Wnt10b) directly. According to a study, Wnt10b plays a crucial role in facilitating tumor progression [76]. Wnt10b aberrant overexpression upregulates the $\mathrm{Wnt} / \beta$-catenin pathway. Therefore, miR-148a regulates the $\mathrm{Wnt} / \beta$-catenin pathway negatively to decrease the expression of stem cell-related genes and inhibit CSCs' self-renewal ability [77].

\section{2. $m i R-215$}

miR-215 is a hypoxia-induced miRNA in CRC stem cells. Hypoxia promotes CSCs to form poorly differentiated colonies. miR-215 acts as a tumor suppressor, which withstands the effect of hypoxia on stemness induction. In the CRC cell lines T6, T18, T20, and T51, miR-215 decreases stem markers' expression, suppresses tumorsphere formation, and reduces CSCs' self-renewal ability by inhibiting leucine-rich repeating-containing G-protein-coupled receptor (LGR5).

LGR5 is a normal intestinal adult stem cell marker [78], which belongs to the G-protein-coupled receptor family. LGR5 is known as a Wnt agonist receptor that is involved in the $\mathrm{Wnt} / \beta$-catenin pathway [79]. So, miR-215 decreases the population of CSCs significantly through by the LGR5-activated Wnt/ß-catenin pathway [80].

\section{3. $m i R-195-5 p$}

In the cell lines SW480, SW620, and HT29, miR-195-5p inhibits CSC stem markers' expression, tumorsphere formation, and reduces cell resistance to 5-FU by inhibiting recombination signal-binding protein of the immunoglobulin kappa J region (RBPJ) and Notch2.

Notch2 is one of the four Notch signal receptors. After binding with Delta ligand, Notch2 undergoes proteolytic cleavage and releases the intracellular domain of Notch (NICD). NICD enters into the nucleus and binds to RBPJ. Consequently, the transcriptions of Notch-targeted genes are activated. The RBPJ-dependent Notch signaling pathway is related with the aggressive CRC tumor phenotype [81]. By negatively regulating the Notch signaling pathway, miR-195-5p decreases the population of CSCs and CRC drug resistance.

\section{4. $m i R-200 c$}

In the CRC cell lines SW480, SW620, HCT116, Lovo, and HT29, the downregulation of miR-200c in CSCs increases tumor sphere formation and self-renewal ability as well as the expression of stem markers. By negatively regulating its downstream target, SOX2, miR-200c inhibits CRC stemness.

SOX2 plays a crucial role in the self-renewal ability of both normal adult stem cells and CSCs [82]. Notably, SOX2 is not only suppressed by miR-200c, but it also affects the expression of miR-200c in return. According to an experiment, two SOX2 transcription factor-binding sites (TFBSs) are found in the miR-200c gene promoter, named TFBS A and B. Studies have shown that it is only when SOX2 
binds to TFBS B alone that it can inhibit miR-200c transcription. Normally, SOX2 binds to TFBS A rather than TFBS B. In addition, miR-200c also suppresses the activation of the PI3K/Akt pathway in CSCs, but the inhibitory effect of miR-200c on the PI3K/Akt pathway can be restored by SOX2. The miR-200c/SOX2 feedback loop finally elevates SOX2 expression and promotes CSCs' characteristics; it should be regarded as a positive feedback loop. However, the reason why the authors recognized it as a negative loop might be that considering miR-200c, it is suppressed by its downstream target. In conclusion, the novel miR-200c/SOX2 negative feedback regulatory loop could be a promising therapeutic target for CRC treatment [83].

\section{5. $m i R-30-5 p$}

In the CRC cell lines Caco2, HT29, HCT15, HCT116, SW620, and SW480, miR-30-5p suppresses stem marker expression and tumorsphere formation, inhibits CSC proliferation, and decreases resistance by inhibiting the expression of ubiquitin-specific peptidase 22 (USP22). USP22 is involved in regulating some oncogenic pathway activation [84]. In CRC, because of the low expression of miR-30-5p, USP22 activates the $\mathrm{Wnt} / \beta$-catenin pathway by increasing the nuclear concentration of $\beta$-catenin, and enhancing cancer stemness and tumorigenesis [85].

\section{6. $m i R-203$}

In CRC, miR-203 plays opposing roles in different stages. For example, the serum miR-203 level of stage III-IV patients is higher than that of stage I-II patients [86] In the CRC cell lines HCT-116 and HT-29, miR-203 acts as a tumor suppressor to suppress tumorsphere formation, self-renewal ability, CSC migration, and the expression of stem markers via direct inhibition of GATA-binding protein 6 (GATA6).

GATA6, which belongs to a small family of zinc finger transcription factors, is responsible for normal intestinal epithelium proliferation and maturation [87], CRC's self-renewal ability, and invasion [88,89]. In CSCs, GATA6 downregulates dickkof-1 (DKK-1), which is a negative effector of the $\mathrm{Wnt} / \beta$-catenin pathway and upregulates LGR5 to activate the $\mathrm{Wnt} / \beta$-catenin pathway.

In short, miR-203 inhibits CRC stemness by suppressing GATA6 and activation of the Wnt/ $\beta$-catenin pathway, indicating that it might contribute to CRC clinical diagnosis and therapy [90].

\section{7. $m i R-139-5 p$}

In the HCT-116 and HT-29 cell lines, miR-139-5p suppress CSCs self-renewal, tumorsphere formation, tumor metastasis, and recurrence as well as stem maker expression via inhibition of transcription factor 4 (TCF4, also known as E2-2).

E2-2 is a basic helix-loop-helix (bHLH) transcription factor of transcription factor 7-like 2 (TCF7L2), which initiates downstream factors of the $\mathrm{Wnt} / \beta$-catenin pathway. In CRC, the overexpression of E2-2 leads to hyperactivation of the Wnt/ $\beta$-catenin pathway, contributing to tumor survival and development [91]. Moreover, E2-2 plays a crucial role in promoting EMT [92]. Notably, E2-2 could be stimulated by external factors to regulate the $\mathrm{Wnt} / \beta$-catenin pathway reversely.

Therefore, by inhibiting E2-2 expression at the protein level, miR-139-5p attenuates CSC stemness, and inhibits tumor metastasis and development [93].

\section{8. $m i R-221$}

In the CRC cell line HCT-116, the overexpression of miR-221 enhances CSCs' self-renewal and tumorsphere formation ability, increases the expression of stem markers, and suppresses apoptosis by inhibiting Quaking-5 (QKI-5).

QKI-5 is the most abundant isoform of QKI and its presence always indicates good prognosis for patients [94]. Additionally, the reduction of QKI is important for CRC development and the stemness maintenance of both normal stem cells and CSCs $[95,96]$. Moreover, QKI-5 is involved in EMT regulation as well [97]. 
miR-221 attenuates the suppressive effect of QKI-5 on CSCs to facilitate enlargement of the CSC population and tumorigenesis. As a result, overexpression of miR-221 usually indicates poor prognosis and a reduced overall survival rate [98].

\section{Prostate Cancer}

Prostate cancer $(\mathrm{PCa})$ is the fourth leading cause of cancer incidence and resulted in 3.6 million deaths worldwide in 2018 [1]. Besides surgery to excise the malignant tumor, androgen deprivation therapy (ADT) is the main choice for patients [99]. However, as the tumor progresses, ADT usually fails due to the transition of tumors to castration-resistant prostate cancer (CRPC), which is a serious challenge in PCa therapy [100]. Nowadays, growing evidence shows that EMT and CSCs play a dominant role in PCa metastasis and resistance. That is to say, PCa therapy focusing on EMT and CSCs may broaden our horizon on PCa treatment.

\section{1. $m i R-449 a$}

In the PCa cell lines PC3 and LNCaP, miR-449a decreases stemness markers' expression and increases CSCs' chemosensitivity by negatively regulating the expression of prostate leucine zipper (PrLZ), an oncogene that belongs to the tumor protein D52 family.

Studies have shown that PrLZ promotes tumorigenesis and is involved in androgen receptor inactivation in CRPC [101]. In addition, PrLZ interferes with AMPK phosphorylation to protect cancer cells from autography in PCa [102]. Aberrantly high expression of PrLZ increases stem markers' expression and promotes CSCs' invasion.

The main mechanism and function of PrLZ, a newly-discovered PCa-specific oncoprotein, in PCa development deserves further investigations, and the miR-499a/PrLZ axis could be a potential target for eradicating PCa CSCs [103].

\section{2. $m i R-7$}

In the PCa cell line PC3, miR-7 also restrains stem markers' expression and tumorsphere formation by inhibiting Krüppel-like factor 4 (KLF4).

KLF4 is a zinc-finger transcription factor. In PCa, KLF4 acts as an oncogene and its overexpression activates the PI3K/Akt pathway. In the CSCs of PCa, the upregulation of KLF4 promotes stem cell proliferation and increases the transcription of stem-associated genes. Moreover, as a downstream effector of the PI3K/Akt pathway, phosphorylated p21 in the cytoplasm is responsible for anti-apoptosis while unphosphorylated p21 in the nucleus contributes to G1-S phase arrest [104]. The expression of miR-7 indirectly suppresses the PI3K/Akt pathway, leading to the accumulation of p21 in the nucleus, which mediates the cell cycle arrest of CSCs and impairs stemness. In sum, by inhibiting the KLF4/PI3K/Akt/p21 pathway, miR-7 attenuates cancer stemness, which is sustained for generations, and miR-7 could be a potential marker for PCa prognosis and treatment [105].

\section{Gastric Cancer}

Gastric cancer (GC) is an aggressive tumor with high diagnostic and mortality rates [106], which is listed as one of the top three most malignant tumors [1]. Because of the lack of early significant symptoms and useful diagnostic techniques, patients are usually diagnosed with gastric cancer at late stages with tumor metastasis, facing poor prognosis and low overall survival rates [107]. So, it is urgent that new diagnostic biomarkers and therapeutic strategies are developed. miRNAs have been confirmed to be involved in gastric tumorigenesis and cancer stemness maintenance.

\section{1. $m i R-21$}

BMI-1 is an oncoprotein whose expression level is upregulated in many types of solid tumors, which is associated with poor prognosis [108]. In the MKN45, SGC-7901, MKN28, and AGS cell lines, 
BMI-1 upregulates the expression of miR-21, which acts as a tumor promoter and increases stem markers' expression, tumorsphere formation, and chemoresistance.

p53, phosphatase, and tensin homolog (PTEN) and reversion-inducing cysteine-rich protein with Kazal motifs (RECK) are downstream targets of miR-21 [109,110]. All three are tumor suppressors. In stem cells, the presence of p53 stops cell differentiation and promotes the conversion of stem cells to progenitor cells [111]. PTEN suppresses the PI3K/Akt pathway to inhibit cell differentiation and induce cell death [112]. RECK plays a role in tumor metastasis and angiogenesis by regulating MMPs. By suppressing p53, PTEN, and RECK expression, miR-21 enhances the stemness properties of CSCs and enlarges the CSC population to promote tumorigenesis and metastasis [113].

\section{2. $\operatorname{miR}-135 b$}

Gastric chronic inflammation increases the tendency of inducing gastric tumorigenesis [114]. Interleukin-1 $\alpha / \beta$ (IL-1 $\alpha / \beta)$ production in gastritis promotes miR-135b expression, which mediates early and advanced gastric carcinogenesis. The aberrant high expression of miR-135b in SNU-719, SNU-601, SNU-638, and AGS cell lines accelerates the rates of tumorsphere formation, CSC differentiation, and growth.

Forkhead box protein N3 (FOXN3) and RECK are downstream targets of miR-135b. As mentioned before, RECK is an inhibitor of MMPs, which often gets suppressed in carcinogenesis. FOXN3, which is downregulated in several cancers as well, binds to the E2F5 promoter to suppress its subsequent transcription $[115,116]$. By inhibiting FOXN3 and RECK mRNA expression, miR-135b contributes to early gastric tumorigenesis and enhances stem-like properties. miR-135b, which is involved in primarily gastritis, shows potent oncogenic effects in inducing gastric carcinogenesis. Therefore, miR-135b has the potential to become a prognostic biomarker for early gastric tumor diagnosis [117].

\section{3. $\operatorname{miR}-577$}

In the cell lines MKN45 and MGC803, transforming growth factor $\beta$ (TGF- $\beta$ ) positively regulates the expression of miR-577 via activation of NF- $\mathrm{kB}$. The high expression of miR-577 indicates poor prognosis and a high recurrence rate, and the overexpression of miR-577 stimulates the expression of stem markers and elevates tumorsphere amounts by suppressing the serum deprivation protein response (SDPR).

Studies have shown that SDPR directly inhibits ERK and then inactivates the NF- $\mathrm{kB}$ pathway [118]. miR-577 suppress SDPR to attenuate its inhibition of the NF- $\mathrm{kB}$ pathway. In consequence, NF- $\mathrm{kB}$ in return stimulates the transcription of miR-577, forming a positive feedback loop.

Considering the crucial role in tumor metastasis and stemness induction, the NF- $\mathrm{kB} / \mathrm{miR}-577 / \mathrm{SDPR}$ feedback loop could be a possible target for gastric cancer treatment [119].

\section{Liver Cancer}

Liver cancer is the fifth most common cancer, and is the third cause of cancer mortality [1]. Liver cancer contains two categories: Primary liver cancer and secondary liver cancer. Primary liver cancer is composed of hepatocellular carcinoma (HCC), intrahepatic cholangiocarcinoma, and mixed-type liver cancer. HCC accounts for $90 \%$ of primary liver cancers, and a high risk of metastasis as well as recurrence is the main reason why these patients usually have poor prognosis [120]. CSCs are responsible for tumor progression, metastasis, and recurrence. Therefore, focusing on CSCs therapy may provide a new prospect for HCC treatment.

\section{1. $m i R-448$}

In the HCC Hep3B cell line, miR-448 works as a tumor suppressor to inhibit stem markers' expression and tumorsphere formation by reducing melanoma-associated antigen 6 (MAGEA6) mRNA expression. 
MAGEA is normally expressed in the testis or placenta and plays a crucial role in germ cell development [121]. Aberrantly high MAGEA expression is usually found in invasive malignant tumors, indicating poor prognosis [122]. MAGEA6 suppresses the activation of adenosine monophosphate-activated protein kinase (AMPK), which leads to either cell cycle arrest or apoptosis in HCC [123]. In addition, the overexpression of MAGA6 in CSCs upregulates the expression of stemness markers and pluripotent genes.

miR-448 acts as a tumor suppressor in CSCs by suppressing MAGEA expression and activating the AMPK signaling pathway, leading to attenuated stemness [124].

\section{2. $m i R-452$}

In the HepG2, HCC-LM3, and Huh7 cell lines, the upregulation of miR-452 not only promotes stem makers' expression and tumorsphere formation but also increases chemoresistance and facilitates cell growth by directly inhibiting SOX7.

SOX7, a tumor suppressor, is downregulated in HCC. SOX7 restrains tumor development by interfering with the Wnt/ $\beta$-catenin signaling pathway [125]. miR-452, which directly suppresses SOX7 expression, is upregulated in the stem cells of HCC and is associated with poor survival rates [126].

\section{3. $\operatorname{miR}-1305$}

In the HCC cell lines HCCLM3, HepG2, Hep3B, and Huh7, miR-1305 restrains CSCs' self-renewal, and the expression of stem markers, and inhibits the tumorsphere quantity by inhibiting the downstream target, ubiquitin-conjugating enzyme E2T (UBE2T).

UBE2T, a member of the ubiquitin-proteasome family, is an oncoprotein in several cancers $[127,128]$. UBE2T overexpression in HCC contributes to the constitutive activation of the Akt/GSK3 $\beta$ signaling pathway. Therefore, CSCs' self-renewal ability and the expression of stemness-associated genes are enhanced. miR-1305 directly targets UBE2T mRNA, and mediates UBE2T's low expression in CSCs, thereby impairing stem cell proliferation and tumorigenesis [129]. For the discovery of the relationship between miR-1305 and UBE2T, the effect of miR-1305 as a prognostic factor in CSC therapy cannot be underestimated.

\section{4. $m i R-302 a / d$}

In the cell lines HepG2 and Huh7 of HCC, miR-302a/d suppresses tumorsphere formation and inhibits CSCs' cell growth by reducing the expression of E2F transcription factor 7 (E2F7).

E2F7 is involved in regulating the cell cycle and its highest expression occurs at the S-phase of the cell cycle [130]. E2F7 is aberrantly overexpressed in the CSCs of HCC, and promotes stem cell proliferation and tumorsphere formation not only through regulating the cell cycle but also activating the Akt/ $\beta$-catenin/cyclin D1 pathway.

miR-302a/d binds to the 3'UTR of E2F7 mRNA and inhibits its translation. The induced miR-302a/d expression in CSCs attenuates the stemness through indirect downregulation of the Akt/ $\beta$-catenin/cyclin D1 pathway, suggesting miR-302a/d is a potential biomarker in HCC stem cell therapy via targeting of E2F7 [131].

\section{5. $m i R-217$}

In the HCC cell lines HepG2 and Huh7, miR-217 acts as oncogenic miRNA to enhance stem cell markers' expression and promote tumorsphere formation by suppressing the expression of DKK1, a Wnt antagonist, leading to hyperactivation of the $\mathrm{Wnt} / \beta$-catenin pathway [132].

\section{6. $m i R-500 a-3 p$}

miR-500a-3p overexpression in HCC is positively associated with poor survival rates. In the HCC cell lines HepG2 and Huh7, miR-500a-3p increases the expression of stem markers and promotes the 
formation of the tumorsphere. miR-500-3p directly targets and inhibits three negative regulators of the Janus kinase/signal transducer and activator of transcription (JAK/STAT) signaling pathway, suppressor of cytokine signaling 2 (SCOS2), SCOS4, and T-cell protein tyrosine phosphatase non-receptor type (PTPN).

The JAK/STAT3 pathway contributes significantly to CSCs' induction and self-renewal [133]. SCOS2 and SCOS4 are two regulators in the negative feedback loop of the JAK/STAT pathway. When SCOS2 and SCOS4 are inhibited, without negative feedback regulation, STAT3 are accumulated in the cytoplasm and nucleus, stimulating pluripotent gene transcription. Studies have shown that high expression of STAT3 in cancer cells positively correlates with tumorigenesis and poor overall survival (OS) [134]. PTPN is an enzyme involved in the removal of phosphate groups from phosphate tyrosine residues to interfere with signal transduction [135].

When the three negative regulators are inhibited, miR-500-3p leads to the constitutive activation of the JAK/STAT3 pathway, and CSCs acquire a strong ability for self-renewal, and the population of CSCs is enlarged [136].

\section{7. $m i R-612$}

In the HCC cell lines HCCLM3 and HepG2, miR-612 acts as a tumor suppressor to inhibit tumorsphere formation and stem marker expression by directly inhibiting specificity protein1 (Sp1).

Sp1 is a TF belonging to the KLF family, and Sp1 interacts with the Nanog promoter and facilitates Nanog transcription. Nanog plays a central role in inducing ESCs' pluripotency [137], and in CSCs, Nanog is upregulated for stemness maintenance. miR-612 directly targets and suppresses Sp1 expression, inhibiting it from binding with the Nanog promoter. Therefore, miR-612 reduces Nanog expression in CSCs.

Consequently, the expression of miR-612 decreases the amount of CSC stem markers and attenuates CSC-like properties in HCC [138]. miR-612, as a novel biomarker, deserves more study as an miRNA-targeting cancer therapy [139-141].

\section{8. $m i R-21-3 p$}

In the HepG2 cell line, miR-21-3p inhibits CSC growth and induces cell apoptosis by suppressing methionine adenosyltransferase (MAT) 2A and 2B.

MAT catalyzes the synthesis of S-adenosylmethionine (SAM). MAT1A and MAT2A are two MAT isoforms: MAT2B encodes an MAT2A regulatory subunit. MAT1A catalyzes more SAM than MAT2A [142]. With the low expression of miR-21-3p, MAT1A expression decreases while MAT2B-mediated MAT2A expression increases in HCC, which is known as "MAT1A:MAT2A switch" [143]. As a result, cells contain a low level of SAM, creating favorable conditions for cell growth [144]. Berberine works as an anti-cancer drug in HCC to induce cell cycle arrest, cell autophagy, and apoptosis [145-147]. After HCC cells undergo berberine treatment, miR-21-3p expression increases, leading to CSC growth suppression and apoptosis induction, indicating their therapeutic potential for HCC treatment [148].

\section{Esophagus Cancer}

Esophagus cancer ranks as the seventh most common cancer and the sixth highest cancer mortality. In 2018, 5.7 million people were diagnosed with esophagus cancer, and 5.1 million people died from esophagus cancer [1]. Esophageal squamous cell carcinoma (ESCC) is the main histological type of esophagus cancer. Other less common types of esophagus cancer are esophageal adenocarcinoma (EAC) and esophageal small cell carcinoma. The reason why esophagus patients are usually diagnosed at a late stage is the lack of effective biomarkers for diagnosis. At the time of diagnosis, tumors have already spread to other parts of the body, with a high relapse rate [149]. Due to the poor prognosis and low survival rate of esophagus patients, research and exploration of new biomarkers and therapies are urgently required. 


\section{1. $m i R-17-5 p$}

In the EAC cell lines OE33 $\mathrm{P}$ and OE33 $\mathrm{R}, \mathrm{miR}-17-5 \mathrm{p}$ is responsible for radiosensitivity and repressing stem-associated gene expression. Chromosome 6 open reading frame 120 (C6orf120) is the downstream target of miR-17, the main function of which is still unknown. C6orf120 expression is elevated in tumor resistance to radiation. Research has shown that C6orf120 could induce primary CD4+ cell apoptosis by mediating intracellular endoplasmic reticulum stress [150].

miR-17-5p suppresses C6orf120 expression to decrease CSCs chemo- and radioresistance. Therefore, miR-17-5p could be a biomarker for CSC resistance evaluation during EAC treatment [151].

\section{2. $m i R-942$}

In the ESCC cell lines Kyse510 and Eca109, miR-942 is significantly overexpressed in ESCC, and promotes a higher level of stem markers and pluripotent gene expression. In the clinic, the overexpression of miR-942 is positively correlated with poor prognosis of patients.

miR-942 suppresses the expression of three negative regulators in the $\mathrm{Wnt} / \beta$-catenin pathway, secreted frizzled-related protein4 (sFRP4), GSK3 $\beta$, and transducin-like enhancer of split 1 (TLE1). The three negative regulators inhibit Wnt signaling transduction at three different levels. As an extracellular Wnt inhibitor, sFRP4 acts as a Wnt antagonist to inhibit Wnt binding to Frizzled receptors [152]. As an intracellular canonical Wnt pathway inhibitor, GSK3 $\beta$ forms a complex with APC and CK1 $\alpha$ to phosphate and degrade $\beta$-catenin [153]. As a nuclear suppressive transcription factor, TLE1 interferes with transcription by suppressing the activity of LEF/TCF [154].

By suppressing sFRP4, GSK3 $\beta$, and TLE1, miR-942 activates the canonical Wnt pathway, and consequently promotes the stem-like properties of CSCs and tumorigenesis [155].

\section{3. $m i R-21-3 p$}

In the ESCC ECa9706, ECa109, KYSE150, and CAES17 cell lines, upregulation of miR-21-3p promotes the expression of stem markers and pluripotent genes, and resists cell apoptosis via inhibition of the tumor necrosis factor receptor-associated factor4 (TRAF4). TRAF4 interacts with p75 ${ }^{\mathrm{NTR}}$ and inhibits subsequent NF-kB pathway activation [156]. miR-21-3p suppresses TRAF4 expression, and p75 ${ }^{\mathrm{NTR}}$ is present in CSCs and activates the NF- $\mathrm{KB}$ pathway, restraining cell apoptosis as well as maintaining CSC phenotypes [157].

\section{Pancreatic Cancer}

Pancreatic cancer is one of the most fatal malignant tumors, with 5-year survival lower than 5\% [158]. Pancreatic ductal adenocarcinoma (PDAC) is the most common pancreatic cancer, characterized as poorly differentiated, invasive, and with an increase in desmoplasia. The high mortality rate is due, in part, to the difficulties in establishing an early and accurate diagnosis as well as to the low rate of operable resection. Most patients are diagnosed too late to perform surgery, therefore studying and developing miRNA-targeting CSC therapy for pancreatic cancer is an urgent matter of our time.

\section{1. $m i R-137$}

In the pancreatic cancer AsPC-1 and PANC-1 cell lines, miR-137 inhibits the expression of both pluripotent genes and stem markers via suppression of downstream KLF12.

KLF12 is another KLF family member. In PDAC, KLF12 positively regulates Dishelleved 2 (DVL2) at the transcriptional level. DVL2 protects $\beta$-catenin from being phosphorylated in the Wnt canonical pathway, therefore KLF12 overexpression in CSCs leads to sustained hyperactivation of the Wnt/ $\beta$-catenin pathway. Induced miR-137 expression reduces CSC phenotypes. Besides inhibiting stemness, through suppression of KLF12, miR-137 suppresses tumorigenesis as well [159]. 


\section{2. $m i R-1181$}

miR-1181 is always downregulated in pancreatic cancer, which indicates poor overall survival and a high recurrence rate. In the pancreatic cancer cell lines AsPC-1 and PANC-1, miR-1181 decreases stem markers and pluripotent gene expression, suppresses tumorsphere formation, and shrinks the CSC population by inhibiting SOX2 and STAT3 expression.

SOX2 overexpression in pancreatic cancer contributes to poor differentiation and high invasion [160]. In CSCs, abnormally high SOX2 expression enlarges the CSC population as well [161]. SOX2 also interacts with STAT3 in the JAK/STAT3 pathway, facilitating the transcription of downstream genes. STAT3 is indispensable in normal pancreas development [162], and its overexpression may lead to pancreatic cancer [163].

By reducing SOX2 and STAT3 expression, miR-1181 attenuates stemness maintenance and impairs carcinogenesis. SOX2 and STAT3 play crucial roles in promoting tumorigenesis and CSC phenotypes, so that the discovery of miR-1181 may provide a novel target for CSC therapy [164].

\section{3. $m i R-30$}

In the pancreatic cancer cell line Capan-1, miR-30 promotes CSC invasion and migration, and the expression of stemness markers as well as increasing cell resistance. Regulated by CD133, miR-30 facilitates carcinogenesis and maintains cancer stemness. The downstream regulatory pathway of miR-30 in pancreatic CSCs is still unknown. Further investigations should be carried out to understand the effects of miR-30 on pancreatic cancer [165].

\section{The Roles of miRNA Clusters in CSC Pathogenesis}

In addition, besides, the dysregulation of single miRNA could be involved in cancer stemness regulation, and some miRNA clusters play vital roles in tumorigenesis, metastasis, and CSC maintenance as well.

The C19MC miRNA cluster on chromosome 19q13.41 is the largest primate-specific miRNA cluster [166]. miRNAs encoded by C19MC are mainly expressed in placental and germinal tissues [167]. Studies have proven that in embryonal tumors with multilayered rosettes (ETMRs), the amplification of C19MC has oncogenic effects on tumorigenesis and CSC development [168]. Additionally, the gene fusion between the TTYH1 promoter and C19MC results in aberrantly high C19MC expression, which can be detected in brain-specific malignant tumors [169]. C19MC oncomiRNAs work cooperatively to inhibit the expression of tumor suppressors, leading to EMTRs' rapid proliferation, accelerated cell cycle, and enriched CSC population. In addition, C19MC upregulates MYCN and lin-28 homolog A (LIN28A) by suppressing tip-tap (TTP). LIN28A regulates epigenetic effecters to promote cell growth, survival, and tumor development. C19MC drives tumor cell growth through MYCN-mediated transcriptional regulator circuity, which also shows therapeutic vulnerability [170]. Moreover, C19MC amplification changes DNA methylation by elevating DNMT3b expression, which promotes cell pluripotency and indicates poor prognosis [171,172]. In testicular germ cell tumor (TGCT), the expression of C19MC in advanced tumor stages and non-seminomas (except teratomas) is higher than others [173].

As another miRNA cluster on chromosome 19, the miR-371-373 cluster is deregulated in parathyroid adenomas (PAds), among which the overexpression of miR-372 inhibits the cell cycle regulators, cyclin-dependent kinase inhibitor 1A (p21/CDKN1A) and large tumor suppressor kinase 2 (LATS2), at both the mRNA and protein levels to protect cells from apoptosis. Moreover, miR-372 upregulates parathormone $(P T H)$ gene expression as well. Interestingly, miR-372 upregulates DKK1 and downregulates CCND1 thus inhibiting the Wnt/ $\beta$-catenin pathway, which may explain the limited proliferation ability of PAds [174].

Normally, the miR-17-92 cluster is transcriptionally suppressed by p53 [175]. In lung adenocarcinoma, as nuclear p53 is lost, miR-17-92 is overexpressed during cancer progression [176]. The upregulation of miR-17-92 inhibits the expression of p38 $\alpha$ protein, an activator of the $\mathrm{Wnt} / \beta$-catenin 
pathway, and the overexpression of leucine-rich repeat-containing G protein-coupled receptor 6 (LGR6). LGR6 is not only an amplifier of the canonical Wnt pathway but a stem marker for CSCs, which enhances CSCs' self-renewal and differentiation [177]. In CSCs of PDAC, the miR-17-92 cluster promoter is hypermethylated by DNMT1. DNMT1 overexpression contributes to high DNA methylation and CSCs' self-renewal via suppression of the miR-17-92 cluster [178].

The murine chromosome 12qF1 miRNA cluster is conserved in the human genome on chromosome $14 \mathrm{q} 32$ and its expression is increased in lung cancer, indicating poor prognosis. Among the miRNA cluster, miR-494-3p enhances CSCs' proliferation, stem marker expression, tumor invasiveness, and metastasis by inhibiting PTEN and promoting the NOTCH pathway [179]. In giant cell tumor of the bone (GCT), five miRNAs of chromosome 14q32 are epigenetically silenced or downregulated in the neoplastic stromal cell population (GCTSC), which may be involved in GCT pathogenesis and might play an important role in the malignant transformation of MSCs [180].

Notably, eight miRNAs of the C19MC cluster having an "AAGUGC" sequence as well as members of the miR-302/-372 miRNA cluster have a positive influence on pluripotency induction and stemness maintenance in mesenchymal stem cells. C19MC-AAGUC miRNAs have a hexamer sequence in the canonical seed region, which is effective in targeting gene silencing. This trait may partially explain the reason for reprogramming cell proliferation, inhibiting cell apoptosis, and inducing pluripotency [181]. Additionally, aberrant activation of C19MC is also detected in various cancers, including HCC, brain tumor, and CRC, which plays a crucial role in enhancing CSC characteristics $[169,182,183]$. In HCC, the presence of C19MC miRNAs indicates a poor prognosis and low survival rate. C19MC promotes poor differentiation of cancer cells' tumor invasion and CSC development [182,184]. In thyroid adenoma, C19MC and miR-371-3 clusters contribute to tumor development and CSC proliferation and enlargement [185]. In parathyroid tumors, miR-372 is upregulated to inhibit cell apoptosis, and increase PTH synthesis and cell proliferation [174]. C19MC-AAGUC miRNAs and miR-302/-372 are positively involved in tumorigenesis and cancer stemness through complex transcriptional regulatory mechanisms, which deserves continuing investigations and may provide a new prospect for CSC reprogramming and cancer therapy in the near future.

\section{Discussion and Conclusions}

miRNAs, a kind of small non-coding RNA about 22-nucleotide-long, regulates 30\% to $50 \%$ of all protein-coding genes' expression at the post-translational level [186]. miRNAs inhibit downstream targets' expression through RNA interference and silencing. Due to the specificity of various cells, different groups of miRNAs are expressed in different cells and tissues in order to produce specific sets of proteins [187]. Nowadays, thousands of human miRNAs have been identified, each of which are estimated to control hundreds of genes [188]. Therefore, with the ongoing exploration of miRNAs, miRNAs' clinical application keeps continuously developing as well, among which miRNA-targeting anti-cancer therapy has aroused great interest and wide concern. CSCs are a subpopulation of heterogenous cancer cells. CSCs share significant characteristics with ESCs, especially an unlimited ability to proliferate, self-renew, and differentiate. Moreover, CSCs also acquire resistance to apoptosis and growth inhibitory signals [189]. Those characteristics make sure that CSCs are able to generate heterogenous tumor cells and finally form an entire tumor after metastasis [190].

Plenty of studies and research have shown that the dysregulation of various miRNAs results in the promotion of CSCs properties. We have summarized the roles of various miRNAs in the eight most common cancers (Table 1) and found that these miRNAs play a crucial role in maintaining CSC phenotypes (Table 2). In addition, we selected several miRNAs and summarized their regulation effects on pathways for CSC maintenance (Figure 2). miRNAs in CSCs play a role as either tumor suppressors or promoters, and influences the CSC characteristics and population by regulating downstream genes' and pathways' activation (Tables 1 and 2). In general, as tumor suppressors, they are repressed so that their oncogenic downstream targets are overexpressed, promoting stemness maintenance. As oncogenes, miRNAs are upregulated in CSCs, and their downstream tumor-suppressive targets are 
suppressed, and as a result, some relative pathways remain constitutively active, which increases the expression of stem-associated genes and enlarges the populations of CSCs.

Lots of studies have paid great attention to the initiated mechanism of CSCs, and two hypotheses have received wide acceptance. One is that due to the accumulation of genetic and epigenetic mutations, normal stem cells have transformed into CSCs, which could explain the reasons for the similar features between normal stem cells and CSCs. Studies have demonstrated that some sets of miRNAs are differently expressed between normal stem cells and CSCs [191]. Using neural stem cells (NSCs) and gliomas cancer stem cells (GSCs) as an example, during NSCs' differentiation, different groups of miRNAs are expressed orderly to help cells convert into mature neural cells. While in GSCs, miRNAs behave as either tumor suppressors or tumor promoters to maintain GSCs' stemness and neural cancer hemostasis. Compared with NSCs, 116 microRNAs are overexpressed, and 62 microRNAs are downregulated in GSCs, among which miR-9 and miR-10b are downregulated as tumor suppressors while miR-7 and miR-124 are upregulated as tumor promoters. In human neural progenitor cells (hNPCs), miR-9 is activated for neurosphere formation and differentiation [192,193]. In GSCs, miR-9 is upregulated as an oncomiRNA to facilitate neurosphere formation, and GSC proliferation and invasion [194]. miR-10b is crucial for spatial regulation [195]. miR-10b is a unique tumor promoter in GSCs and is absent in NSCs. High expression of miR-10b leads to uncontrol growth of GSCs [196-198]. As a brain-specific miRNA, miR-7 overexpression in NSCs is essential for synapse formation and neurite growth. In GSCs, miR-7 expression is suppressed to promote cell proliferation. Otherwise, miR-7 will induce GSCs' death by inhibiting several downstream effectors of epidermal growth factor receptor (EGFR) [199]. miR-124 is essential for neural lineage commitment [200,201]. miR-124 is a unique neural miRNA suppressed in GSCs, and miR-124 expression decreases neurosphere formation and stemness markers' expression, as well as G1 cell cycle arrest [202]. The miRNA network plays a crucial role in the conversion of normal stem cells to CSCs. Changes of miRNA expression may help to distinguish between normal stem cells and CSCs, which has a positive influence on the early diagnosis and treatment of cancer [203].

The other is that differentiated tumor cells could return to CSCs and reacquire stemness properties with changes of the transcriptome. The reversible transformation between CSCs and differentiated tumor cells may better explain the heterogeneity of cancer cells [204]. The transcriptome means the entire set of transcripts in a cell or a certain population of cells. As a part of the transcriptome, long-noncoding RNAs (lncRNAs) are involved in various cellular activities by regulating miRNA expression, mRNA stability and processing, as well as protein stability [205]. For example, in osteosarcoma, IncRNA Fer-1-like protein 4 (FER1L4) inhibits miR18a-5p to induce CSCs apoptosis, and suppress the PI3K/Akt pathway and EMT [206]. In CRC, zinc finger E-box-binding homeobox 2 antisense lncRNA (ZEB2-AS1) directly regulates its mRNA to promote ZEB2 translation $[207,208]$. In gastric cancer, lncRNA00261 is downregulated because it interacts with slug/GSK3 $\beta$ protein complex, causing slug degradation [209]. Each miRNA could control hundreds or thousands of mRNAs by binding their 3'UTR. Generally, miRNAs always inhibit downstream mRNA expression. However, some miRNAs could promote mRNA expression. For example, pre-miRNAs can induce methylation of gene promoters to stimulate gene expression [210]. RNA-binding proteins (RBPs) occur in every step of RNA processing and the expression of RBPs varies in different tumors [211]. For instance, musashi RNA-binding protein 1 (MSI1) is overexpressed in many kinds of CSCs [212-214], and suppresses the expression of NUMB endocytic adaptor protein (NUMB) and JAGGED1, which are two negative regulators of the Notch signaling pathway $[215,216]$. The epitranscriptome containing all cellular RNA modifications is significant in regulating gene expression. N6-methyladenosine $\left(\mathrm{m}^{6} \mathrm{~A}\right)$, the most common mRNA modification, plays a fundamental role in promoting CSCs' self-renewal. It modifies mRNA through a reversible process in which m6A could be removed by "erasers" [217]. In glioblastoma stem cells (GBCs), the removal of methyltransferase-like 3 (Mettl3) and Mettl14 induces a high level of $\mathrm{m}^{6} \mathrm{~A}$ mRNA expression, which promotes CSCs' self-renewal and tumorigenesis [218]. 
Table 1. microRNAs (miRNAs) and their downstream signaling pathways in various cancer stem cells (CSCs).

\begin{tabular}{|c|c|c|c|c|c|}
\hline miRNAs & Cancers & Cell Lines & Suppressor/Promoter & Signaling Pathways & References \\
\hline miR-122 & NSCLC & A549,H460, HCC 827 & Suppressor & $\operatorname{PrxII} \downarrow \rightarrow$ Hedgehog, Notch, Wnt/ $\beta$-catenin pathway $\downarrow$ & [28] \\
\hline $\operatorname{miR}-128$ & $\mathrm{LC}$ & A549/PTX & Suppressor & BMI-1, MUC1-C $\downarrow \rightarrow$ PI3K/Akt, MEK/ERK pathway $\downarrow$ & [32] \\
\hline miR-19 & $\mathrm{LC}$ & A549, H1299 & Promoter & GSK3 $\beta \downarrow \rightarrow$ Wnt $/ \beta$-catenin pathway $\uparrow$ & [10] \\
\hline $\operatorname{miR}-410$ & NSCLC & A549, H1299 & Promoter & GSK $3 \beta \downarrow \rightarrow W n t / \beta$-catenin pathway $\uparrow$ & [37] \\
\hline $\operatorname{miR}-30$ & NSCLC & SPC-A1, NCI-H1650 & Suppressor & TM4SF1 $\downarrow \rightarrow$ PI3K/AKT pathway $\downarrow$ & {$[40]$} \\
\hline $\operatorname{miR}-127$ & $\mathrm{LC}$ & PC9, A549 & Promoter & TNFAIP $\_\downarrow \rightarrow$ NF- $k$ B pathway $\uparrow$ & [44] \\
\hline miR-129-5p & NSCLC & A549, H460 & Suppressor & DLK1 $\downarrow$ & [47] \\
\hline $\operatorname{miR}-181 b$ & NSCLC & H1650, H1299, A549 & Suppressor & Notch $2 \downarrow \rightarrow$ Notch pathway $\downarrow$ & [48] \\
\hline $\operatorname{miR}-34 a$ & $\mathrm{BC}$ & MCF-7 & Suppressor & PRKD1 $\downarrow \rightarrow G S K 3 / \beta$-catenin pathway $\downarrow$ & {$[52]$} \\
\hline $\operatorname{miR}-34 a$ & $\mathrm{BC}$ & MCF-7 & Suppressor & SIRT1 $\downarrow \rightarrow$ P53 acetylation and activation $\uparrow$ & [59] \\
\hline $\operatorname{miR}-34 a$ & $\mathrm{BC}$ & MCF-7 & Suppressor & Notch $1 \downarrow \rightarrow$ Notch pathway $\downarrow$ & {$[61]$} \\
\hline miR-185-3p & $\mathrm{BC}$ & $\begin{array}{c}\text { MDA-MB-468, } \\
\text { MDA-MB-231, } \\
\text { MDA-MB-453, MCF-7 }\end{array}$ & Suppressor & $\mathrm{E} 2 \mathrm{~F} 1 \downarrow \rightarrow \mathrm{Nanog} \downarrow$ & {$[62]$} \\
\hline miR-590-5p & $\mathrm{BC}$ & MCF-7, ZR75-1 & Suppressor & SOX $2 \downarrow$ & {$[65]$} \\
\hline $\operatorname{miR}-33 b$ & $\mathrm{BC}$ & $\begin{array}{l}\text { MCF-7, MDA-MB-231, } \\
\text { BT-549, MDA-MB-453, } \\
\text { SK-BR-3, 4T1 }\end{array}$ & Suppressor & HMGA2, SALL4, Twist1 $\downarrow$ & [66] \\
\hline miR-137 & TNBC & MDA-MB-231, SUM149 & Suppressor & BCL11A $\downarrow \rightarrow$ BCL11A-DNMT1 interaction $\downarrow$ & [69] \\
\hline $\operatorname{miR}-873$ & $\mathrm{BC}$ & MCF-7, MDA-MB-231 & Suppressor & PD-L1 $\downarrow \rightarrow$ PI3K/Akt, MAPK/ERK signaling pathway $\downarrow$ & [71] \\
\hline miR-221 & $\mathrm{BC}$ & T47D & Promoter & DNMT3b $\downarrow \rightarrow$ some pluripotent gene expression $\uparrow$ & [73] \\
\hline miR-148a & CRC & SW480 & Suppressor & WNT10b $\downarrow \rightarrow W n t / \beta$-catenin pathway $\downarrow$ & [77] \\
\hline $\operatorname{miR}-215$ & CRC & T6, T18, T20, T51 & Suppressor & LGR5 $\downarrow \rightarrow$ Wnt $/ \beta$-catenin pathway $\downarrow$ & [80] \\
\hline miR-195-5p & CRC & $\begin{array}{c}\text { SW480, SW620, HT-29, } \\
\text { HCT-160 }\end{array}$ & Suppressor & Notch2, RBPJ $\downarrow \rightarrow$ Notch pathway $\downarrow$ & [81] \\
\hline
\end{tabular}


Table 1. Cont.

\begin{tabular}{|c|c|c|c|c|c|}
\hline miRNAs & Cancers & Cell Lines & Suppressor/Promoter & Signaling Pathways & References \\
\hline miR-200c & CRC & $\begin{array}{l}\text { SW480, SW620, HCT116, } \\
\text { Lovo, HT29 }\end{array}$ & Suppressor & SOX2, PI3K, Akt $\downarrow \rightarrow$ PI3K/Akt pathway $\downarrow$ & {$[83]$} \\
\hline $\operatorname{miR}-30-5 p$ & $\mathrm{CRC}$ & $\begin{array}{c}\text { Caco2, HT29, HCT15, } \\
\text { HCT116, SW620, SW480 }\end{array}$ & Suppressor & USP22 $\downarrow \rightarrow \beta$-catenin $\downarrow \rightarrow$ Wnt $/ \beta$-catenin pathway $\downarrow$ & {$[85]$} \\
\hline miR-203 & CRC & НCТ-116, НТ-29 & Suppressor & $\begin{array}{c}\text { GATA6 } \downarrow \rightarrow \text { LGR5 } \downarrow, \text { DKK- } 1 \uparrow \rightarrow \text { Wnt } / \beta \text {-catenin } \\
\text { pathway } \downarrow\end{array}$ & {$[90]$} \\
\hline miR-139-5p & CRC & HCT-116, HT-29 & suppressor & E2-2 $\downarrow \rightarrow$ Wnt $/ \beta$-catenin pathway $\downarrow$, EMT $\downarrow$ & [93] \\
\hline $\operatorname{miR}-221$ & CRC & HCT-116 & Promoter & 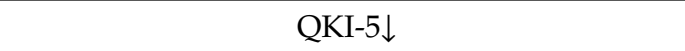 & [98] \\
\hline $\operatorname{miR}-449 a$ & $\mathrm{PCa}$ & PC3, LNCaP & Suppressor & $\operatorname{PrLZ} \downarrow \rightarrow \mathrm{AMPK} \downarrow$ & [103] \\
\hline miR-7 & $\mathrm{PCa}$ & PC3 & Suppressor & KLF4 $\downarrow \rightarrow$ PI3K/Akt/p21 pathway $\downarrow$ & [105] \\
\hline $\operatorname{miR}-21$ & GC & $\begin{array}{l}\text { MKN45, SGC-7901, } \\
\text { MKN28, AGS }\end{array}$ & Promoter & P53, PTEN, RECK $\downarrow \rightarrow$ PTEN/Akt pathway $\uparrow$ & [113] \\
\hline miR-135b & GC & $\begin{array}{l}\text { SNU-719, SNU-601, } \\
\text { SNU-638, AGS }\end{array}$ & Promoter & $\mathrm{FOXN} 3, \mathrm{RECK} \downarrow \rightarrow \mathrm{E} 2 \mathrm{~F} 5 \uparrow$ & [117] \\
\hline $\mathrm{miR}-577$ & GC & MKN45, MGC803 & Promoter & SDPR $\downarrow \rightarrow \mathrm{NF}-\mathrm{kB} / \mathrm{miR}-577 / \mathrm{SDPR}$ axis $\uparrow$ & [119] \\
\hline $\operatorname{miR}-448$ & $\mathrm{HCC}$ & Нер3В & Suppressor & MAGEA6 $\downarrow \rightarrow$ AMPK $\uparrow$ & [124] \\
\hline $\mathrm{miR}-452$ & HCC & HepG2, HCC-LM3, Huh7 & Promoter & SOX7 $\downarrow \rightarrow W n t / \beta$-catenin pathway $\uparrow$ & [126] \\
\hline miR-1305 & $\mathrm{HCC}$ & $\begin{array}{c}\text { HCCLM3, HepG2, Hep3B, } \\
\text { Huh7 }\end{array}$ & Suppressor & $\mathrm{UBE} 2 \mathrm{~T} \downarrow \rightarrow \mathrm{Akt} / \mathrm{GSK} 3 \beta$ pathway $\downarrow$ & [129] \\
\hline $\mathrm{miR}-302 \mathrm{a} / \mathrm{d}$ & HCC & HepG2, Huh7 & Suppressor & E2F7 $\downarrow \rightarrow A K T / \beta$-catenin/cyclinD1 pathway $\downarrow$ & [131] \\
\hline miR-217 & $\mathrm{HCC}$ & HepG2, Huh7 & Promoter & $\mathrm{DKK} 1 \downarrow \rightarrow \mathrm{Wnt} / \beta$-catenin pathway $\uparrow$ & [132] \\
\hline $\operatorname{miR}-500 a-3 p$ & $\mathrm{HCC}$ & HepG2, Huh7 & Promoter & SOCS2, SOCS4, PTPN $\downarrow \rightarrow$ JAK/STAT3 pathway $\uparrow$ & [136] \\
\hline $\operatorname{miR}-612$ & $\mathrm{HCC}$ & HCCLM3, HepG2 & Suppressor & $\mathrm{SP} 1 \downarrow \rightarrow \mathrm{SP} 1 /$ Nanog signaling $\downarrow$ & [138] \\
\hline miR-21-3p & $\mathrm{HCC}$ & HepG2 & Suppressor & MAT2A, MAT2B $\downarrow \rightarrow$ SAM $\downarrow$ & [148] \\
\hline miR-17-5p & EAC & OE33 P, OE33 R & Suppressor & 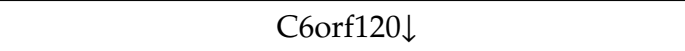 & [151] \\
\hline
\end{tabular}


Table 1. Cont

\begin{tabular}{|c|c|c|c|c|c|}
\hline miRNAs & Cancers & Cell Lines & Suppressor/Promoter & Signaling Pathways & References \\
\hline $\operatorname{miR}-942$ & ESCC & Kyse510, Eca109 & Promoter & sFRP4, GSK $3 \beta$ and TLE1 $\downarrow \rightarrow W n t / \beta$-catenin pathway $\uparrow$ & [155] \\
\hline miR-21-3p & ESCC & $\begin{array}{l}\text { ECa9706, ECa109, } \\
\text { KYSE150, CAES17 }\end{array}$ & Promoter & TRAF4 $\downarrow \rightarrow$ NF-kB pathway $\uparrow$ & [157] \\
\hline $\operatorname{miR}-137$ & $\begin{array}{l}\text { Pancreatic } \\
\text { cancer }\end{array}$ & AsPC-1, PANC-1 & Suppressor & KLF12 $\downarrow \rightarrow W n t / \beta$-catenin pathway $\downarrow$ & [159] \\
\hline $\operatorname{miR}-1181$ & $\begin{array}{l}\text { Pancreatic } \\
\text { cancer }\end{array}$ & AsPC-1, PANC-1 & Suppressor & SOX2, STAT3 $\downarrow \rightarrow$ JAK/STAT3 pathway $\downarrow$ & {$[164]$} \\
\hline miR-30 & $\begin{array}{l}\text { Pancreatic } \\
\text { cancer }\end{array}$ & Capan-1 & Promoter & unknown & [165] \\
\hline
\end{tabular}

Abbreviations: NSCLC, non-small cell lung cancer; LC, lung cancer; BC, breast cancer; TNBC, triple-negative breast cancer; CRC, colorectal cancer; PCa, prostate cancer; GC, gastric cancer; HCC, hepatocellular carcinoma; EAC, esophageal adenocarcinoma; ESCC, esophageal squamous cell carcinoma; Prx II, peroxiredoxin II; MUC1-C, mucin 1-C; GSK3 $\beta$, glycogen synthase kinase 3 $\beta$; TM4SF1, transmembrane-4 L-six family member-1; TNFAIP3, targeting tumor necrosis factor alpha-induced 3; DLK1, delta-like 1 homolog; PRKD1, serine/threonine-protein kinase D1; SIRT1, suppressing sirtuin1; E2F1, E2F transcription factor 1; SOX2, SRY-box transcription factor 2; HMGA2, high mobility group AT-hook 2; SALL4, spalt like transcription factor 4; Twist1, twist family bHLH transcription factor 1; BCL11A, B-cell lymphoma/leukemia 11A; PD-L1, programmed cell death ligand 1; DNMT3b, DNA methyltransferase 3b; LGR5, leucine-rich repeating-containing G-protein coupled receptor; RBPJ, recombination signal binding protein for immunoglobulin kappa J region; USP22, ubiquitin-specific peptidase 22; GATA6, GATA binding protein 6; E2-2, transcription factor4; QKI-5, Quaking-5; PrLZ, prostate leucine zipper; KLF4, Krüppel-like factor 4; PTEN, phosphatase and tensin homolog; SDPR, serum deprivation protein response; MAGEA6, melanoma-associated antigen 6; UBE2T, ubiquitin-conjugating enzyme E2T; E2F7, E2F transcription factor 7; DKK1, dickkof-1; SCOS2, suppressor of cytokine signaling 2; SCOS4, suppressor of cytokine signaling 4; PTPN, T-cell protein tyrosine phosphatase non-receptor type; Sp1, specificity protein1; MAT2A, methionine adenosyltransferase 2A; MAT2B, methionine adenosyltransferase 2B; C6orf120, chromosome 6 open reading frame 120; sFRP4, secreted frizzled-related protein4; TLE1, transducin-like enhancer of split 1; TRAF4, tumor necrosis factor receptor associated factor4; KLF12, Krüppel-like factor 12. 
Table 2. The effects of miRNAs on CSC phenotypes in various cancers.

\begin{tabular}{|c|c|c|c|c|c|}
\hline miRNAs & Cancers & Cell Lines & Suppressor/Promoter & $\begin{array}{l}\text { Effects on } \\
\text { Stemness }\end{array}$ & References \\
\hline miR-122 & NSCLC & A549, H460, HCC827 & Suppressor & inhibit I, IV, V & [28] \\
\hline miR-128 & LC & A549/PTX & Suppressor & inhibit I, IV, V & [32] \\
\hline miR-19 & $\mathrm{LC}$ & A549, H1299 & Promoter & promote I, V & [10] \\
\hline miR-410 & NSCLC & A549, H1299 & Promoter & promote I, IV, V & [37] \\
\hline miR-30 & NSCLC & SPC-A1, NCI-H1650 & Suppressor & suppress I & [40] \\
\hline miR-127 & $\mathrm{LC}$ & PC9, A549 & Promoter & promote I, IV, V & [44] \\
\hline miR-129-5p & NSCLC & A549, H460 & Suppressor & suppress I, IV, V & [47] \\
\hline $\mathrm{miR}-181 \mathrm{~b}$ & NSCLC & H1650, H1299, A549 & Suppressor & suppress I, IV, V & [48] \\
\hline miR-34a & $\mathrm{BC}$ & MCF-7 & Suppressor & suppress I, IV, V & [52] \\
\hline miR-34a & $\mathrm{BC}$ & MCF-7 & Suppressor & suppress I, V & [59] \\
\hline miR-34a & $\mathrm{BC}$ & MCF-7 & Suppressor & suppress I, IV, V & [61] \\
\hline miR-185-3p & $\mathrm{BC}$ & $\begin{array}{l}\text { MDA-MB-468, } \\
\text { MDA-MB-231, } \\
\text { MDA-MB-453, } \\
\text { MCF-7 }\end{array}$ & Suppressor & suppress I, V & [62] \\
\hline miR-590-5p & $\mathrm{BC}$ & MCF-7, ZR75-1 & Suppressor & suppress I, V & [65] \\
\hline miR-33b & $\mathrm{BC}$ & $\begin{array}{c}\text { MCF-7, } \\
\text { MDA-MB-231, } \\
\text { BT-549, } \\
\text { MDA-MB-453, } \\
\text { SK-BR-3, 4T1 }\end{array}$ & Suppressor & suppress I, V & {$[66]$} \\
\hline miR-137 & TNBC & $\begin{array}{l}\text { MDA-MB-231, } \\
\text { SUM149 }\end{array}$ & Suppressor & suppress I, V & [69] \\
\hline miR-873 & $\mathrm{BC}$ & $\begin{array}{c}\text { MCF-7, } \\
\text { MDA-MB-231 }\end{array}$ & Suppressor & suppress I, II, IV, V & {$[71]$} \\
\hline miR-221 & $\mathrm{BC}$ & T47D & Promoter & promote I, V & [73] \\
\hline miR-148a & CRC & SW480 & Suppressor & suppress I, IV, V & [77] \\
\hline miR-215 & CRC & T6, T18, T20, T51 & Suppressor & suppress I, V & [80] \\
\hline miR-195-5p & CRC & $\begin{array}{l}\text { SW480, SW620, } \\
\text { HT-29, HCT-160 }\end{array}$ & Suppressor & suppress I, IV, V & [81] \\
\hline miR-200c & CRC & $\begin{array}{c}\text { SW480, SW620, } \\
\text { HCT116, Lovo, HT29 }\end{array}$ & Suppressor & suppress I, V & [83] \\
\hline $\operatorname{miR}-30-5 p$ & CRC & $\begin{array}{c}\text { Caco2, HT29, HCT15, } \\
\text { HCT116, SW620, } \\
\text { SW480 }\end{array}$ & Suppressor & suppress I, IV, V & [85] \\
\hline miR-203 & CRC & HCT-116, HT-29 & Suppressor & Suppress I, V & [90] \\
\hline miR-139-5p & CRC & HCT-116, HT-29 & Suppressor & Suppress I, IV, V & [93] \\
\hline miR-221 & CRC & HCT-116 & Promoter & Promote I, V & [98] \\
\hline miR-449a & $\mathrm{PCa}$ & PC-3, LNCaP & Suppressor & suppress IV & [103] \\
\hline miR-7 & $\mathrm{PCa}$ & PC3 & Suppressor & suppress I, V & [105] \\
\hline miR-21 & GC & $\begin{array}{l}\text { MKN45, SGC-7901, } \\
\text { MKN28, AGS }\end{array}$ & Promoter & promote I, IV, V & [113] \\
\hline $\operatorname{miR}-135 b$ & GC & $\begin{array}{l}\text { SNU-719, SNU-601, } \\
\text { SNU-638, AGS }\end{array}$ & Promoter & promote I, II & [117] \\
\hline miR-577 & GC & MKN45, MGC803 & Promoter & promote I, V & [119] \\
\hline miR-448 & $\mathrm{HCC}$ & Нер3В & Suppressor & promote I, V & [124] \\
\hline $\operatorname{miR}-452$ & $\mathrm{HCC}$ & $\begin{array}{c}\text { HepG2, HCC-LM3, } \\
\text { Huh7 }\end{array}$ & Promoter & promote I, IV, V & [126] \\
\hline
\end{tabular}


Table 2. Cont.

\begin{tabular}{cccccc}
\hline miRNAs & Cancers & Cell Lines & Suppressor/Promoter & $\begin{array}{c}\text { Effects on } \\
\text { Stemness }\end{array}$ & References \\
\hline miR-1305 & HCC & $\begin{array}{c}\text { HCCLM3, HepG2, } \\
\text { Hep3B, Huh7 }\end{array}$ & Suppressor & suppress I, V & {$[129]$} \\
\hline miR-302a/d & HCC & HepG2, Huh7 & Suppressor & suppress I & {$[131]$} \\
\hline miR-217 & HCC & HepG2, Huh7 & Promoter & promote I, V & {$[132]$} \\
\hline miR-500a-3p & HCC & HepG2, Huh7 & Promoter & promote I, V & {$[136]$} \\
\hline miR-612 & HCC & HCCLM3, HepG2 & Suppressor & suppress I, V & {$[138]$} \\
\hline miR-21-3p & HCC & HepG2 & suppressor & suppress I & {$[148]$} \\
\hline miR-17-5p & EAC & OE33 P, OE33 R & Suppressor & suppress IV & {$[151]$} \\
\hline miR-942 & ESCC & Kyse510, Eca109 & Promoter & promote V & {$[155]$} \\
\hline miR-21-3p & ESCC & $\begin{array}{c}\text { ECa9706, ECa109, } \\
\text { KYSE150, CAES17 }\end{array}$ & Promoter & promote V & {$[157]$} \\
\hline miR-137 & $\begin{array}{c}\text { Pancreatic } \\
\text { cancer }\end{array}$ & AsPC-1, PANC-1 & Suppressor & suppress V & {$[159]$} \\
\hline miR-1181 & $\begin{array}{c}\text { Pancreatic } \\
\text { cancer }\end{array}$ & AsPC-1, PANC-1 & Suppressor & suppress I, V & {$[164]$} \\
\hline miR-30 & $\begin{array}{c}\text { Pancreatic } \\
\text { caner }\end{array}$ & Capan-1 & Promoter & promote, IV, V & {$[165]$}
\end{tabular}

Abbreviations: NSCLC, non-small cell lung cancer; LC, lung cancer; TNBC, triple-negative breast cancer; CRC, colorectal cancer; PCa, prostate cancer; GC, gastric cancer; HCC, hepatocellular carcinoma; EAC, esophageal adenocarcinoma; ESCC, esophageal squamous cell carcinoma. Notes: I. CSCs have self-renew ability and form tumorsphere for proliferation. II. A few CSCs are able to form an entire tumor. III. CSCs in recipient can be transplanted to the next recipient. IV. CSCs are responsible for tumor recurrence and chemoresistance. V. CSCs have many specific stem markers on the cell membrane.

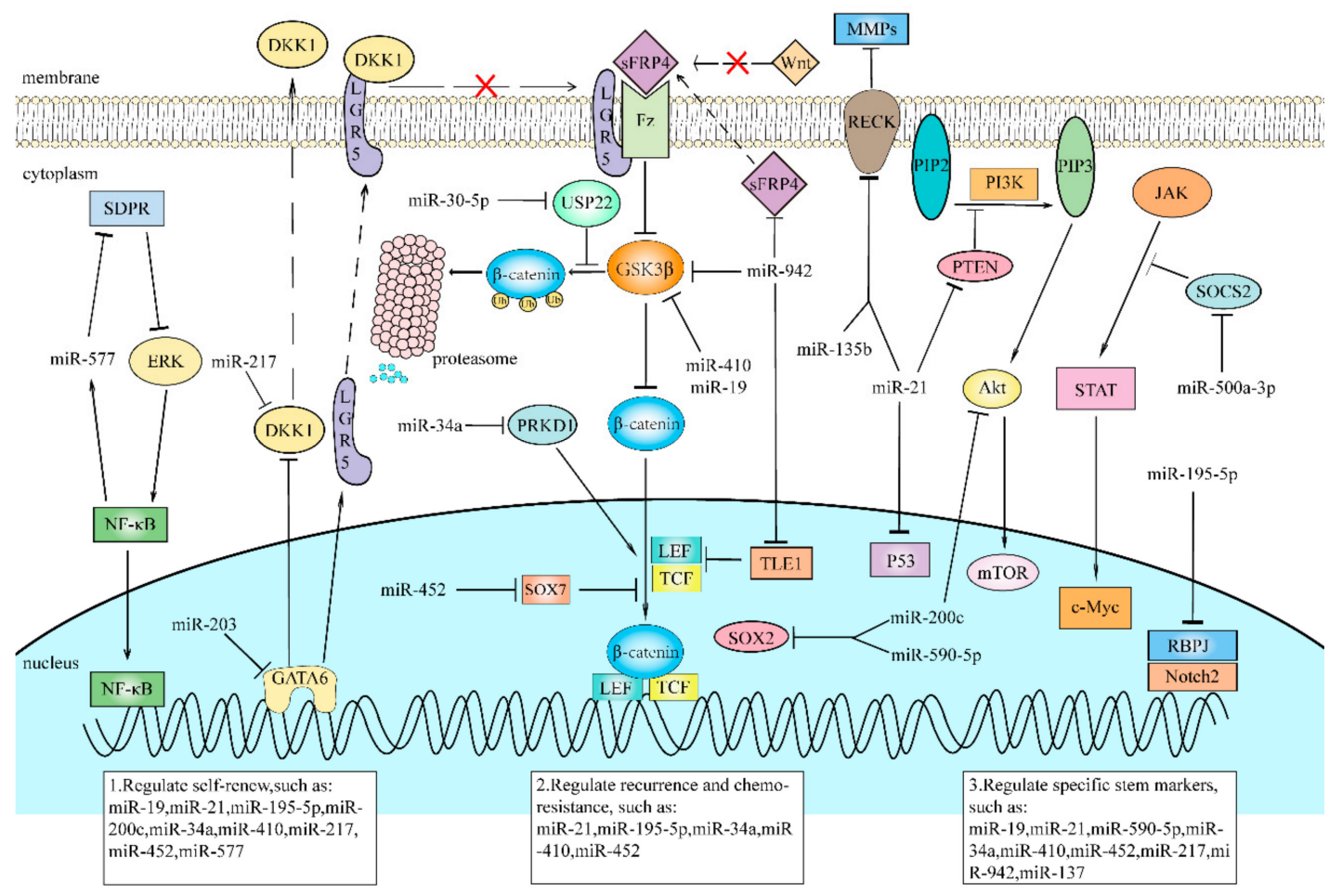

Figure 2. Some miRNAs regulate important pathways to affect CSCs' maintenance via targeting of their downstream targets.

CSCs' properties, such as self-renewal and therapeutic resistance, are closely related with transcriptional and post-transcriptional mechanisms. Increasing amounts of research focusing on this 
topic have gradually revealed the mechanisms related to cancer stemness and how they interact with each other. Efforts made on this topic will be of great advantage for us to reach a deep understanding of the initiated mechanism of CSCs, which will cast a new light on future cancer prevention and early diagnosis. Especially, the study of CSCs' therapeutic resistance will set up a bridge to connect scientific research and clinical therapy, hoping to provide new insights for clinic doctors to work against therapeutic resistance during cancer treatment and elevate prognosis and overall survival for patients.

Moreover, in some less common cancers, miRNA dysregulation also contributes to carcinogenesis and CSC development as well. In the ovarian cancer cell lines A2780CP20 and SKOV3ip1, miR-21-3p promotes cell proliferation and increases drug resistance by suppressing RNA-binding protein with multiple splicing (RBPMS), POZ domain containing protein 1 (RCBTB1), and zinc finger protein 608 (ZNF 608). Involved in the phosphorylation of SMAD2 and SMAD4 [219], RCBTB1 plays a role in regulating the cell cycle [220]. ZNF608 is associated with transcriptional events [221]. By inhibiting those three downstream targets, miR-21-3p contributes to tumorigenesis and CSC proliferation [222]. In the cervical cancer cell lines Hela, CaSki, Siha, and C33A, miR-23b decreases the tumorsphere amount and size, suppresses stem marker expression, and decreases cell resistance to cisplastin via inhibition of the expression of aldehyde dehydrogenase 1 family member A1 (ALDHA1) [223]. As a marker of tumors, high expression of ALDH1A1 is positively associated with poor prognosis [224]. In the bladder cancer cell lines 5637, BIU87, EJ, SCaBER, and T24, miR-139-5p shrinks the tumorsphere size and amount, and inhibits stem marker and pluripotent gene expression by suppressing BMI-1 [225].

Notably, even the same miRNA may play opposing roles in different tumors. In some tumors, it acts as a suppressor while in other tumors, it acts as a promoter. Take miR-21-3p as an example. The limited and inefficient studies of miR-21-3p show that miR-21-3p plays opposing roles in different cancer tissues. In gastric cancer, the expression of miR-21 facilitates the formation of the tumorsphere and increases the chemoresistance of CSCs by downregulating p53, PTEN, and RECK. In ESCC, miR-21-3p upregulates the expression of stem markers and pluripotent genes, and restrains cell apoptosis by suppressing TRAF4. However, in HCC, miR-21-3p creates an unsuitable environment for CSC growth and induces cell apoptosis by inhibiting MAT2A and MAT2B. It is obvious that miR-21-3p possesses several downstream targets, and in different cancers, miR-21-3p interferes with differing mRNA translation to influence downstream signaling pathway activation. Nevertheless, the specific molecular mechanism of miR-21-3p is still unknown. Another dual-effect miRNA is miR-30. In NSCLC and CRC, miR-30 acts as a tumor suppressor while in pancreatic cancer, miR-30 behaves as a tumor promoter. In NSCLC, miR-30 inhibits cell growth and tumorsphere formation and induces cell apoptosis by negatively targeting TM4SF1, which contributes to PI3K/Akt pathway activation. In CRC, miR-30-5p suppresses stem markers' expression, tumorsphere formation, and cell proliferation; decreases CSC resistance by inhibiting USP22; and indirectly attenuates activation of the $W n t / \beta$-catenin pathway. However, CD133 upregulates the expression of miR-30 in pancreatic cancer, miR-30 facilitates CSCs' self-renewal and tumorsphere formation, and increases the expression of stem markers and cell resistance. Downstream targets of miR-30 in pancreatic cancer are still unclear, which deserves further research. miRNAs with opposing effects in different tumors usually regulate multiple pathways' activation, and studies on those dual-effect miRNAs will cast new light on cancer research and clinical therapy.

As one of the main characteristics of CSCs, therapeutic resistance is the main problem for clinical therapy. Additionally, apoptosis is a significant sign for evaluating therapeutic effect and resistance [226]. Studies have shown that miRNAs play an important role in regulating therapeutic resistance of CSCs. In NSCLC, the low expression of miR-122 promotes Prx II expression and inhibits ROS intracellular levels to reduce cell apoptosis. Besides, the low expression of miR-30 inhibits cell apoptosis by activating TM4SF1. In lung cancer, miR-127 acts as an oncogenic miRNA to inhibit cell apoptosis and increase therapeutic resistance via inhibition of TNFAIP3. TNFAIP3 is a negative regulator of the NF- $\kappa B$ pathway. In $B C$, miR- 873 increases chemo and drug sensitivity via suppression of the immune checkpoint PD-L1 expression. In PCa, PrLZ is related to androgen receptor inactivation, 
contributing to CRPC. miR-449a elevates CSCs; chemosensitivity by inhibiting PrLZ directly, which provides a new landscape for avoiding CRPC during PCa therapy. In HCC, miR-21-3p suppresses MAT2A and MAT2B to increase SAM expression, impairing hepatoma cell growth. While in ESCC, miR-21-3p promotes cell repair and restrains apoptosis via inhibition of TRAF4 expression. TRAF4 is a p53-regulated gene and is involved in inducing cell apoptosis as well as suppressing tumorsphere formation [227]. Plenty of research has proven the importance of miRNAs in the therapeutic resistance of CSCs, and some miRNAs might be used as new targets for sensitizing CSCs to clinical treatment via induction of their apoptosis.

Although huge progression has been made during recent years in the field of cancer treatment, both therapeutic resistance and tumor recurrence are still thorny problems that need to be solved. Current chemotherapy and radiotherapy mainly focuses on killing rapidly dividing cells rather than slow dividing cells; therefore, CSCs evade elimination, with the ability of forming an entire tumor [228]. So, that is the reason of why CSCs are the main reason that resistance and tumor recurrence occurs. Studies have shown that the tumor can be almost eliminated by targeting and destroying CSCs [229-231]. CSCs produce plenty of biomolecules, including miRNAs, which have the potential to become valid biomarkers for cancer diagnosis and anticancer therapy. Each miRNA might control hundreds of genes [232], and the dysregulation of miRNAs contributes to the upregulation of pluripotent or multipotent genes as well as stemness factors in CSCs, enhancing stemness phenotypes. That is to say, through altering miRNA expression, complex regulation to suppress CSC proliferation and elimination of the whole tumor may be achieved (Figure 3) [233].

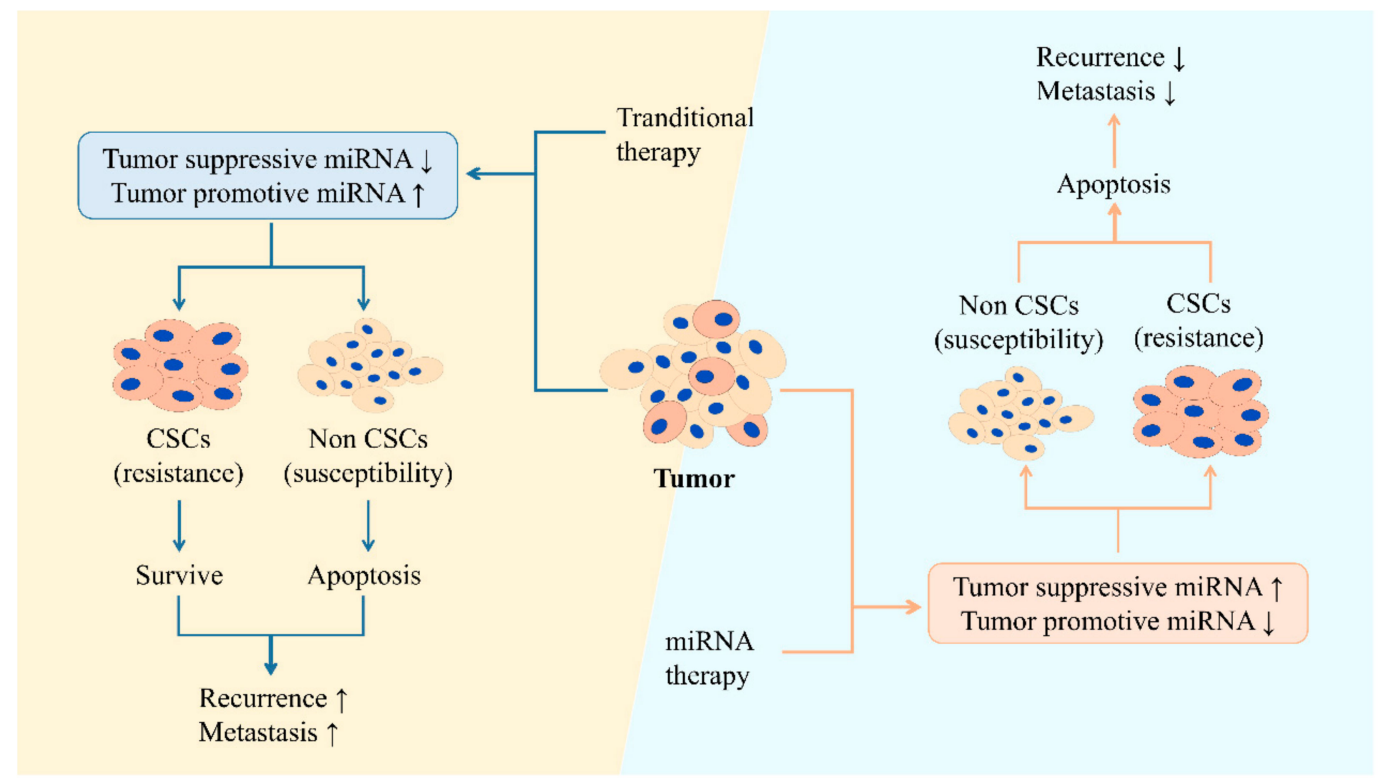

Figure 3. Differences between traditional anti-cancer therapy and miRNA therapy. Traditional therapy mainly kills non-CSCs while CSCs survive with higher therapeutic resistance. By altering the relative miRNA expression in the tumor, miRNA therapy induces CSCs' apoptosis, lowering the possibility of tumor recurrence and metastasis.

Compared with traditional cancer treatments, miRNA-targeting CSC therapy may decrease recurrence and therapeutic resistance, as well as prolong the survival of cancer patients via elimination of both regular cancer cells and CSCs. Moreover, miRNAs have the potential to be developed into effective biomarkers for cancer diagnosis and prognosis. With the progressive understanding and ongoing investigation of CSCs, and new anti-cancer approaches targeting CSCs combined with traditional anti-cancer therapies in the near future, total heterogeneous tumor cells would be removed with little probability of recurrence or therapeutic resistance. However, it is worth noting that miRNA-targeting CSC therapy may be accompanied with some side effects, which deserve attention. 
For instance, when designing CSCs' prognostic factors or therapeutic targets, how to distinguish CSCs from normal stem cells or somatic cells and avoid destroying normal stem cells when killing CSCs deserves attention. In conclusion, understanding the specific mechanisms of different miRNAs in maintaining the stemness of different CSCs should benefit us tremendously in the field of cancer research and clinical therapy.

Author Contributions: Writing—original draft preparation, X.J.; writing—review and editing, X.Q.; figures and tables, L.W.; resources, B.L.; conceptualization, Y.W.; visualization, X.K.; project administration, L.X. All authors have read and agreed to the published version of the manuscript.

Funding: This work was supported by the National Natural Science Foundation of China (No. 31860317).

Acknowledgments: We would like to appreciate WHO providing cancer related statistical data.

Conflicts of Interest: The authors declare no conflict of interest.

\section{References}

1. Bray, F.; Ferlay, J.; Soerjomataram, I.; Siegel, R.L.; Torre, L.A.; Jemal, A. Global cancer statistics 2018: GLOBOCAN estimates of incidence and mortality worldwide for 36 cancers in 185 countries. CA Cancer J. Clin. 2018, 68, 394-424. [CrossRef] [PubMed]

2. Ferlay, J.; Colombet, M.; Soerjomataram, I.; Mathers, C.; Parkin, D.M.; Pineros, M.; Znaor, A.; Bray, F. Estimating the global cancer incidence and mortality in 2018: GLOBOCAN sources and methods. Int. J. Cancer 2019, 144, 1941-1953. [CrossRef] [PubMed]

3. Chang, J.C. Cancer stem cells: Role in tumor growth, recurrence, metastasis, and treatment resistance. Medicine (Baltimore) 2016, 95, S20-S25. [CrossRef] [PubMed]

4. Singh, A.; Settleman, J. EMT, cancer stem cells and drug resistance: An emerging axis of evil in the war on cancer. Oncogene 2010, 29, 4741-4751. [CrossRef] [PubMed]

5. Ajani, J.A.; Song, S.; Hochster, H.S.; Steinberg, I.B. Cancer stem cells: The promise and the potential. Semin. Oncol. 2015, 42 (Suppl. S1), S3-S17. [CrossRef]

6. Prasad, S.; Ramachandran, S.; Gupta, N.; Kaushik, I.; Srivastava, S.K. Cancer cells stemness: A doorstep to targeted therapy. Biochim. Biophys. Acta Mol. Basis Dis. 2019. [CrossRef] [PubMed]

7. Lapidot, T.; Sirard, C.; Vormoor, J.; Murdoch, B.; Hoang, T.; Caceres-Cortes, J.; Minden, M.; Paterson, B.; Caligiuri, M.A.; Dick, J.E. A cell initiating human acute myeloid leukaemia after transplantation into SCID mice. Nature 1994, 367, 645-648. [CrossRef] [PubMed]

8. Bonnet, D.; Dick, J.E. Human acute myeloid leukemia is organized as a hierarchy that originates from a primitive hematopoietic cell. Nat. Med. 1997, 3, 730-737. [CrossRef]

9. Bu, Y.; Cao, D. The origin of cancer stem cells. Front. Biosci. (Sch. Ed.) 2012, 4, 819-830.

10. Zhu, J.; Wang, S.; Chen, Y.; Li, X.; Jiang, Y.; Yang, X.; Li, Y.; Wang, X.; Meng, Y.; Zhu, M.; et al. miR-19 targeting of GSK3beta mediates sulforaphane suppression of lung cancer stem cells. J. Nutr. Biochem. 2017, 44, 80-91. [CrossRef]

11. Chen, L.S.; Wang, A.X.; Dong, B.; Pu, K.F.; Yuan, L.H.; Zhu, Y.M. A new prospect in cancer therapy: Targeting cancer stem cells to eradicate cancer. Chin. J. Cancer 2012, 31, 564-572. [CrossRef] [PubMed]

12. Tang, C.; Ang, B.T.; Pervaiz, S. Cancer stem cell: Target for anti-cancer therapy. FASEB J. 2007, 21, 3777-3785. [CrossRef] [PubMed]

13. Desai, A.; Yan, Y.; Gerson, S.L. Concise Reviews: Cancer Stem Cell Targeted Therapies: Toward Clinical Success. Stem Cells Transl. Med. 2019, 8, 75-81. [CrossRef] [PubMed]

14. Deonarain, M.P.; Kousparou, C.A.; Epenetos, A.A. Antibodies targeting cancer stem cells: A new paradigm in immunotherapy? $m A$ ss 2009, 1, 12-25. [CrossRef]

15. Yadav, A.K.; Desai, N.S. Cancer Stem Cells: Acquisition, Characteristics, Therapeutic Implications, Targeting Strategies and Future Prospects. Stem Cell Rev. Rep. 2019, 15, 331-355. [CrossRef]

16. Takahashi, R.U.; Miyazaki, H.; Ochiya, T. The role of microRNAs in the regulation of cancer stem cells. Front. Genet. 2014, 4, 295. [CrossRef]

17. Raza, U.; Zhang, J.D.; Sahin, O. MicroRNAs: Master regulators of drug resistance, stemness, and metastasis. J. Mol. Med. (Berl.) 2014, 92, 321-336. [CrossRef] 
18. Filipowicz, W.; Bhattacharyya, S.N.; Sonenberg, N. Mechanisms of post-transcriptional regulation by microRNAs: Are the answers in sight? Nat. Rev. Genet. 2008, 9, 102-114. [CrossRef]

19. Friedman, R.C.; Farh, K.K.; Burge, C.B.; Bartel, D.P. Most mammalian mRNAs are conserved targets of microRNAs. Genome Res. 2009, 19, 92-105. [CrossRef]

20. Bartel, D.P. MicroRNAs: Genomics, biogenesis, mechanism, and function. Cell 2004, 116, 281-297. [CrossRef]

21. Zhang, B.; Pan, X.; Cobb, G.P.; Anderson, T.A. microRNAs as oncogenes and tumor suppressors. Dev. Biol. 2007, 302, 1-12. [CrossRef] [PubMed]

22. Ham, S.Y.; Kwon, T.; Bak, Y.; Yu, J.H.; Hong, J.; Lee, S.K.; Yu, D.Y.; Yoon, D.Y. Mucin 1-mediated chemo-resistance in lung cancer cells. Oncogenesis 2016, 5, e185. [CrossRef] [PubMed]

23. Jopling, C. Liver-specific microRNA-122: Biogenesis and function. RNA Biol. 2012, 9, 137-142. [CrossRef] [PubMed]

24. Ma, L.; Liu, J.; Shen, J.; Liu, L.; Wu, J.; Li, W.; Luo, J.; Chen, Q.; Qian, C. Expression of miR-122 mediated by adenoviral vector induces apoptosis and cell cycle arrest of cancer cells. Cancer Biol. Ther. 2010, 9, 554-561. [CrossRef] [PubMed]

25. Rhee, S.G.; Chae, H.Z.; Kim, K. Peroxiredoxins: A historical overview and speculative preview of novel mechanisms and emerging concepts in cell signaling. Free Radic. Biol. Med. 2005, 38, 1543-1552. [CrossRef]

26. Lu, Y.; Zhang, X.S.; Zhou, X.M.; Gao, Y.Y.; Chen, C.L.; Liu, J.P.; Ye, Z.N.; Zhang, Z.H.; Wu, L.Y.; Li, W.; et al. Peroxiredoxin $1 / 2$ protects brain against $\mathrm{H} 2 \mathrm{O} 2$-induced apoptosis after subarachnoid hemorrhage. FASEB J. 2019, 33, 3051-3062. [CrossRef]

27. Park, Y.H.; Kim, S.U.; Lee, B.K.; Kim, H.S.; Song, I.S.; Shin, H.J.; Han, Y.H.; Chang, K.T.; Kim, J.M.; Lee, D.S.; et al. Prx I suppresses K-ras-driven lung tumorigenesis by opposing redox-sensitive ERK/cyclin D1 pathway. Antioxid. Redox Signal. 2013, 19, 482-496. [CrossRef]

28. Chandimali, N.; Huynh, D.L.; Zhang, J.J.; Lee, J.C.; Yu, D.Y.; Jeong, D.K.; Kwon, T. MicroRNA-122 negatively associates with peroxiredoxin-II expression in human gefitinib-resistant lung cancer stem cells. Cancer Gene Ther. 2018. [CrossRef]

29. Siddique, H.R.; Saleem, M. Role of BMI1, a stem cell factor, in cancer recurrence and chemoresistance: Preclinical and clinical evidences. Stem Cells 2012, 30, 372-378. [CrossRef]

30. Yuan, W.; Yuan, Y.; Zhang, T.; Wu, S. Role of Bmi-1 in regulation of ionizing irradiation-induced epithelial-mesenchymal transition and migration of breast cancer cells. PLoS ONE 2015, 10, e0118799. [CrossRef]

31. Kharbanda, A.; Rajabi, H.; Jin, C.; Alam, M.; Wong, K.K.; Kufe, D. MUC1-C confers EMT and KRAS independence in mutant KRAS lung cancer cells. Oncotarget 2014, 5, 8893-8905. [CrossRef] [PubMed]

32. Koh, H.; Park, H.; Chandimali, N.; Huynh, D.L.; Zhang, J.J.; Ghosh, M.; Gera, M.; Kim, N.; Bak, Y.; Yoon, D.Y.; et al. MicroRNA-128 suppresses paclitaxel-resistant lung cancer by inhibiting MUC1-C and BMI-1 in cancer stem cells. Oncotarget 2017, 8, 110540-110551. [CrossRef] [PubMed]

33. Li, J.; Yang, S.; Yan, W.; Yang, J.; Qin, Y.J.; Lin, X.L.; Xie, R.Y.; Wang, S.C.; Jin, W.; Gao, F.; et al. MicroRNA-19 triggers epithelial-mesenchymal transition of lung cancer cells accompanied by growth inhibition. Lab. Investig. 2015, 95, 1056-1070. [CrossRef] [PubMed]

34. Kahn, M. Can we safely target the WNT pathway? Nat. Rev. Drug Discov. 2014, 13, 513-532. [CrossRef] [PubMed]

35. Teng, Y.; Wang, X.; Wang, Y.; Ma, D. Wnt/beta-catenin signaling regulates cancer stem cells in lung cancer A549 cells. Biochem. Biophys. Res. Commun. 2010, 392, 373-379. [CrossRef] [PubMed]

36. Venugopal, A.; Subramaniam, D.; Balmaceda, J.; Roy, B.; Dixon, D.A.; Umar, S.; Weir, S.J.; Anant, S. RNA binding protein RBM3 increases beta-catenin signaling to increase stem cell characteristics in colorectal cancer cells. Mol. Carcinog. 2016, 55, 1503-1516. [CrossRef] [PubMed]

37. Ke, X.; Yuan, Y.; Guo, C.; Yang, Y.; Pu, Q.; Hu, X.; Tang, K.; Luo, X.; Jiang, Q.; Su, X.; et al. MiR-410 induces stemness by inhibiting Gsk3beta but upregulating beta-catenin in non-small cells lung cancer. Oncotarget 2017, 8, 11356-11371. [CrossRef]

38. Cao, R.; Wang, G.; Qian, K.; Chen, L.; Ju, L.; Qian, G.; Wu, C.L.; Dan, H.C.; Jiang, W.; Wu, M.; et al. TM4SF1 regulates apoptosis, cell cycle and ROS metabolism via the PPARgamma-SIRT1 feedback loop in human bladder cancer cells. Cancer Lett. 2018, 414, 278-293. [CrossRef] 
39. Gao, H.; Chakraborty, G.; Zhang, Z.; Akalay, I.; Gadiya, M.; Gao, Y.; Sinha, S.; Hu, J.; Jiang, C.; Akram, M.; et al. Multi-organ Site Metastatic Reactivation Mediated by Non-canonical Discoidin Domain Receptor 1 Signaling. Cell 2016, 166, 47-62. [CrossRef]

40. Ma, Y.S.; Yu, F.; Zhong, X.M.; Lu, G.X.; Cong, X.L.; Xue, S.B.; Xie, W.T.; Hou, L.K.; Pang, L.J.; Wu, W.; et al. miR-30 Family Reduction Maintains Self-Renewal and Promotes Tumorigenesis in NSCLC-Initiating Cells by Targeting Oncogene TM4SF1. Mol. Ther. 2018, 26, 2751-2765. [CrossRef]

41. Edwards, C.A.; Mungall, A.J.; Matthews, L.; Ryder, E.; Gray, D.J.; Pask, A.J.; Shaw, G.; Graves, J.A.; Rogers, J.; Dunham, I.; et al. The evolution of the DLK1-DIO3 imprinted domain in mammals. PLoS Biol. 2008, 6, e135. [CrossRef] [PubMed]

42. Ito, M.; Sferruzzi-Perri, A.N.; Edwards, C.A.; Adalsteinsson, B.T.; Allen, S.E.; Loo, T.H.; Kitazawa, M.; Kaneko-Ishino, T.; Ishino, F.; Stewart, C.L.; et al. A trans-homologue interaction between reciprocally imprinted miR-127 and Rt11 regulates placenta development. Development 2015, 142, 2425-2430. [CrossRef] [PubMed]

43. Zakaria, N.; Mohd Yusoff, N.; Zakaria, Z.; Widera, D.; Yahaya, B.H. Inhibition of NF-kappaB Signaling Reduces the Stemness Characteristics of Lung Cancer Stem Cells. Front. Oncol. 2018, 8, 166. [CrossRef] [PubMed]

44. Shi, L.; Wang, Y.; Lu, Z.; Zhang, H.; Zhuang, N.; Wang, B.; Song, Z.; Chen, G.; Huang, C.; Xu, D.; et al. miR-127 promotes EMT and stem-like traits in lung cancer through a feed-forward regulatory loop. Oncogene 2017, 36, 1631-1643. [CrossRef] [PubMed]

45. Kouhkan, F.; Mobarra, N.; Soufi-Zomorrod, M.; Keramati, F.; Hosseini Rad, S.M.; Fathi-Roudsari, M.; Tavakoli, R.; Hajarizadeh, A.; Ziaei, S.; Lahmi, R.; et al. MicroRNA-129-1 acts as tumour suppressor and induces cell cycle arrest of GBM cancer cells through targeting IGF2BP3 and MAPK1. J. Med. Genet. 2016, 53, 24-33. [CrossRef] [PubMed]

46. Zhong, Z.; Ye, Y.; Guo, W.; He, Y.; Hu, W. Relationship between DLK1 gene promoter region DNA methylation and non-small cell lung cancer biological behavior. Oncol. Lett. 2017, 13, 4123-4126. [CrossRef]

47. Ma, Z.; Cai, H.; Zhang, Y.; Chang, L.; Cui, Y. MiR-129-5p inhibits non-small cell lung cancer cell stemness and chemoresistance through targeting DLK1. Biochem. Biophys. Res. Commun. 2017, 490, 309-316. [CrossRef]

48. Wang, X.; Meng, Q.; Qiao, W.; Ma, R.; Ju, W.; Hu, J.; Lu, H.; Cui, J.; Jin, Z.; Zhao, Y.; et al. miR-181b/Notch2 overcome chemoresistance by regulating cancer stem cell-like properties in NSCLC. Stem Cell Res. Ther. 2018, 9, 327. [CrossRef]

49. Foulkes, W.D.; Smith, I.E.; Reis-Filho, J.S. Triple-negative breast cancer. N. Engl. J. Med. 2010, 363, $1938-1948$. [CrossRef]

50. Spasojevic, C.; Marangoni, E.; Vacher, S.; Assayag, F.; Meseure, D.; Chateau-Joubert, S.; Humbert, M.; Karam, M.; Ricort, J.M.; Auclair, C.; et al. PKD1 is a potential biomarker and therapeutic target in triple-negative breast cancer. Oncotarget 2018, 9, 23208-23219. [CrossRef]

51. Yuan, J.; Liu, Y.; Tan, T.; Guha, S.; Gukovsky, I.; Gukovskaya, A.; Pandol, S.J. Protein kinase d regulates cell death pathways in experimental pancreatitis. Front. Physiol. 2012, 3, 60. [CrossRef] [PubMed]

52. Kim do, Y.; Park, E.Y.; Chang, E.; Kang, H.G.; Koo, Y.; Lee, E.J.; Ko, J.Y.; Kong, H.K.; Chun, K.H.; Park, J.H. A novel miR-34a target, protein kinase D1, stimulates cancer stemness and drug resistance through GSK3/beta-catenin signaling in breast cancer. Oncotarget 2016, 7, 14791-14802. [CrossRef] [PubMed]

53. Sundram, V.; Chauhan, S.C.; Jaggi, M. Emerging roles of protein kinase D1 in cancer. Mol. Cancer Res. 2011, 9, 985-996. [CrossRef] [PubMed]

54. Eiseler, T.; Doppler, H.; Yan, I.K.; Goodison, S.; Storz, P. Protein kinase D1 regulates matrix metalloproteinase expression and inhibits breast cancer cell invasion. Breast Cancer Res. 2009, 11, R13. [CrossRef] [PubMed]

55. Borges, S.; Doppler, H.; Perez, E.A.; Andorfer, C.A.; Sun, Z.; Anastasiadis, P.Z.; Thompson, E.; Geiger, X.J.; Storz, P. Pharmacologic reversion of epigenetic silencing of the PRKD1 promoter blocks breast tumor cell invasion and metastasis. Breast Cancer Res. 2013, 15, R66. [CrossRef]

56. Sharma, A.; Gautam, V.; Costantini, S.; Paladino, A.; Colonna, G. Interactomic and pharmacological insights on human sirt-1. Front. Pharmacol. 2012, 3, 40. [CrossRef] [PubMed]

57. Calvanese, V.; Fraga, M.F. SirT1 brings stemness closer to cancer and aging. Aging (Albany N. Y.) 2011, 3, 162-167. [CrossRef]

58. Yamakuchi, M.; Lowenstein, C.J. MiR-34, SIRT1 and p53: The feedback loop. Cell Cycle 2009, 8, 712-715. [CrossRef] 
59. Ma, W.; Xiao, G.G.; Mao, J.; Lu, Y.; Song, B.; Wang, L.; Fan, S.; Fan, P.; Hou, Z.; Li, J.; et al. Dysregulation of the miR-34a-SIRT1 axis inhibits breast cancer stemness. Oncotarget 2015, 6, 10432-10444. [CrossRef]

60. Liu, S.; Wicha, M.S. Targeting breast cancer stem cells. J. Clin. Oncol. 2010, 28, 4006-4012. [CrossRef]

61. Kang, L.; Mao, J.; Tao, Y.; Song, B.; Ma, W.; Lu, Y.; Zhao, L.; Li, J.; Yang, B.; Li, L. MicroRNA-34a suppresses the breast cancer stem cell-like characteristics by downregulating Notch1 pathway. Cancer Sci. 2015, 106, 700-708. [CrossRef] [PubMed]

62. Lu, G.; Li, Y.; Ma, Y.; Lu, J.; Chen, Y.; Jiang, Q.; Qin, Q.; Zhao, L.; Huang, Q.; Luo, Z.; et al. Long noncoding RNA LINC00511 contributes to breast cancer tumourigenesis and stemness by inducing the miR-185-3p/E2F1/Nanog axis. J. Exp. Clin. Cancer Res. 2018, 37, 289. [CrossRef] [PubMed]

63. Okita, K.; Yamanaka, S. Induction of pluripotency by defined factors. Exp. Cell Res. 2010, 316, 2565-2570. [CrossRef]

64. Johari, B.; Zargan, J. Simultaneous targeted inhibition of Sox2-Oct4 transcription factors using decoy oligodeoxynucleotides to repress stemness properties in mouse embryonic stem cells. Cell Biol. Int. 2017, 41, 1335-1344. [CrossRef] [PubMed]

65. Zhou, L.; Zhao, L.C.; Jiang, N.; Wang, X.L.; Zhou, X.N.; Luo, X.L.; Ren, J. MicroRNA miR-590-5p inhibits breast cancer cell stemness and metastasis by targeting SOX2. Eur. Rev. Med. Pharmacol. Sci. 2017, 21, 87-94.

66. Lin, Y.; Liu, A.Y.; Fan, C.; Zheng, H.; Li, Y.; Zhang, C.; Wu, S.; Yu, D.; Huang, Z.; Liu, F.; et al. MicroRNA-33b Inhibits Breast Cancer Metastasis by Targeting HMGA2, SALL4 and Twist1. Sci. Rep. 2015, 5, 9995. [CrossRef]

67. Herrera-Merchan, A.; Cerrato, C.; Luengo, G.; Dominguez, O.; Piris, M.A.; Serrano, M.; Gonzalez, S. miR-33-mediated downregulation of p53 controls hematopoietic stem cell self-renewal. Cell Cycle 2010, 9, 3277-3285. [CrossRef]

68. Pathania, R.; Ramachandran, S.; Elangovan, S.; Padia, R.; Yang, P.; Cinghu, S.; Veeranan-Karmegam, R.; Arjunan, P.; Gnana-Prakasam, J.P.; Sadanand, F.; et al. DNMT1 is essential for mammary and cancer stem cell maintenance and tumorigenesis. Nat. Commun. 2015, 6, 6910. [CrossRef]

69. Chen, F.; Luo, N.; Hu, Y.; Li, X.; Zhang, K. MiR-137 Suppresses Triple-Negative Breast Cancer Stemness and Tumorigenesis by Perturbing BCL11A-DNMT1 Interaction. Cell. Physiol. Biochem. 2018, 47, 2147-2158. [CrossRef]

70. Patel, S.P.; Kurzrock, R. PD-L1 Expression as a Predictive Biomarker in Cancer Immunotherapy. Mol. Cancer Ther. 2015, 14, 847-856. [CrossRef]

71. Gao, L.; Guo, Q.; Li, X.; Yang, X.; Ni, H.; Wang, T.; Zhao, Q.; Liu, H.; Xing, Y.; Xi, T.; et al. MiR-873/PD-L1 axis regulates the stemness of breast cancer cells. EBioMedicine 2019, 41, 395-407. [CrossRef] [PubMed]

72. Chen, T.; Ueda, Y.; Dodge, J.E.; Wang, Z.; Li, E. Establishment and maintenance of genomic methylation patterns in mouse embryonic stem cells by Dnmt3a and Dnmt3b. Mol. Cell. Biol. 2003, 23, 5594-5605. [CrossRef] [PubMed]

73. Roscigno, G.; Quintavalle, C.; Donnarumma, E.; Puoti, I.; Diaz-Lagares, A.; Iaboni, M.; Fiore, D.; Russo, V.; Todaro, M.; Romano, G.; et al. MiR-221 promotes stemness of breast cancer cells by targeting DNMT3b. Oncotarget 2016, 7, 580-592. [CrossRef] [PubMed]

74. Esteller, M. Cancer epigenomics: DNA methylomes and histone-modification maps. Nat. Rev. Genet. 2007, 8, 286-298. [CrossRef]

75. Gao, Q.; Steine, E.J.; Barrasa, M.I.; Hockemeyer, D.; Pawlak, M.; Fu, D.; Reddy, S.; Bell, G.W.; Jaenisch, R. Deletion of the de novo DNA methyltransferase Dnmt3a promotes lung tumor progression. Proc. Natl. Acad. Sci. USA 2011, 108, 18061-18066. [CrossRef]

76. Wend, P.; Wend, K.; Krum, S.A.; Miranda-Carboni, G.A. The role of WNT10B in physiology and disease. Acta Physiol. (Oxf.) 2012, 204, 34-51. [CrossRef]

77. Shi, L.; Xi, J.; Xu, X.; Peng, B.; Zhang, B. MiR-148a suppressed cell invasion and migration via targeting WNT10b and modulating beta-catenin signaling in cisplatin-resistant colorectal cancer cells. Biomed. Pharmaco. Ther. 2019, 109, 902-909. [CrossRef] [PubMed]

78. Trepp, C.; Quintela Pousa, A.M.; Enzmann, V. Transcriptome Analysis Did Not Show Endogenous Stem Cell Characteristics in Murine Lgr5(+) Retinal Cells. Int. J. Mol. Sci. 2019, 20. [CrossRef]

79. Chen, M.; Tian, S.; Glasgow, N.G.; Gibson, G.; Yang, X.; Shiber, C.E.; Funderburgh, J.; Watkins, S.; Johnson, J.W.; Schuman, J.S.; et al. Lgr5(+) amacrine cells possess regenerative potential in the retina of adult mice. Aging Cell 2015, 14, 635-643. [CrossRef] 
80. Ullmann, P.; Nurmik, M.; Schmitz, M.; Rodriguez, F.; Weiler, J.; Qureshi-Baig, K.; Felten, P.; Nazarov, P.V.; Nicot, N.; Zuegel, N.; et al. Tumor suppressor miR-215 counteracts hypoxia-induced colon cancer stem cell activity. Cancer Lett. 2019, 450, 32-41. [CrossRef]

81. Jin, Y.; Wang, M.; Hu, H.; Huang, Q.; Chen, Y.; Wang, G. Overcoming stemness and chemoresistance in colorectal cancer through miR-195-5p-modulated inhibition of notch signaling. Int. J. Biol. Macromol. 2018, 117, 445-453. [CrossRef] [PubMed]

82. Gangemi, R.M.; Griffero, F.; Marubbi, D.; Perera, M.; Capra, M.C.; Malatesta, P.; Ravetti, G.L.; Zona, G.L.; Daga, A.; Corte, G. SOX2 silencing in glioblastoma tumor-initiating cells causes stop of proliferation and loss of tumorigenicity. Stem Cells 2009, 27, 40-48. [CrossRef] [PubMed]

83. Lu, Y.X.; Yuan, L.; Xue, X.L.; Zhou, M.; Liu, Y.; Zhang, C.; Li, J.P.; Zheng, L.; Hong, M.; Li, X.N. Regulation of colorectal carcinoma stemness, growth, and metastasis by an miR-200c-Sox2-negative feedback loop mechanism. Clin. Cancer Res. 2014, 20, 2631-2642. [CrossRef] [PubMed]

84. Yang, X.; Chen, Y.; Chen, L. The Versatile Role of microRNA-30a in Human Cancer. Cell. Physiol. Biochem. 2017, 41, 1616-1632. [CrossRef] [PubMed]

85. Jiang, S.; Miao, D.; Wang, M.; Lv, J.; Wang, Y.; Tong, J. MiR-30-5p suppresses cell chemoresistance and stemness in colorectal cancer through USP22/Wnt/beta-catenin signaling axis. J. Cell. Mol. Med. 2019, 23, 630-640. [CrossRef] [PubMed]

86. Sun, Y.; Liu, Y.; Cogdell, D.; Calin, G.A.; Sun, B.; Kopetz, S.; Hamilton, S.R.; Zhang, W. Examining plasma microRNA markers for colorectal cancer at different stages. Oncotarget 2016, 7, 11434-11449. [CrossRef] [PubMed]

87. Beuling, E.; Aronson, B.E.; Tran, L.M.; Stapleton, K.A.; ter Horst, E.N.; Vissers, L.A.; Verzi, M.P.; Krasinski, S.D. GATA6 is required for proliferation, migration, secretory cell maturation, and gene expression in the mature mouse colon. Mol. Cell. Biol. 2012, 32, 3392-3402. [CrossRef]

88. Belaguli, N.S.; Aftab, M.; Rigi, M.; Zhang, M.; Albo, D.; Berger, D.H. GATA6 promotes colon cancer cell invasion by regulating urokinase plasminogen activator gene expression. Neoplasia 2010, 12, 856-865. [CrossRef] [PubMed]

89. Whissell, G.; Montagni, E.; Martinelli, P.; Hernando-Momblona, X.; Sevillano, M.; Jung, P.; Cortina, C.; Calon, A.; Abuli, A.; Castells, A.; et al. The transcription factor GATA6 enables self-renewal of colon adenoma stem cells by repressing BMP gene expression. Nat. Cell Biol. 2014, 16, 695-707. [CrossRef]

90. Lai, H.T.; Tseng, W.K.; Huang, S.W.; Chao, T.C.; Su, Y. MicroRNA-203 diminishes the stemness of human colon cancer cells by suppressing GATA6 expression. J. Cell. Physiol. 2019. [CrossRef]

91. Mologni, L.; Dekhil, H.; Ceccon, M.; Purgante, S.; Lan, C.; Cleris, L.; Magistroni, V.; Formelli, F.; Gambacorti-Passerini, C.B. Colorectal tumors are effectively eradicated by combined inhibition of \{beta\}-catenin, KRAS, and the oncogenic transcription factor ITF2. Cancer Res. 2010, 70, 7253-7263. [CrossRef] [PubMed]

92. Sobrado, V.R.; Moreno-Bueno, G.; Cubillo, E.; Holt, L.J.; Nieto, M.A.; Portillo, F.; Cano, A. The class I bHLH factors E2-2A and E2-2B regulate EMT. J. Cell Sci. 2009, 122, 1014-1024. [CrossRef] [PubMed]

93. Ma, X.; Liu, J.; Li, J.; Li, Y.; Le, V.M.; Li, S.; Liang, X.; Liu, L.; Liu, J. miR-139-5p reverses stemness maintenance and metastasis of colon cancer stem-like cells by targeting E2-2. J. Cell. Physiol. 2019, 234, 22703-22718. [CrossRef] [PubMed]

94. Darbelli, L.; Richard, S. Emerging functions of the Quaking RNA-binding proteins and link to human diseases. Wiley Interdiscip. Rev. RNA 2016, 7, 399-412. [CrossRef]

95. Ji, S.; Ye, G.; Zhang, J.; Wang, L.; Wang, T.; Wang, Z.; Zhang, T.; Wang, G.; Guo, Z.; Luo, Y.; et al. miR-574-5p negatively regulates Qki6/7 to impact beta-catenin/Wnt signalling and the development of colorectal cancer. Gut 2013, 62, 716-726. [CrossRef]

96. Shingu, T.; Ho, A.L.; Yuan, L.; Zhou, X.; Dai, C.; Zheng, S.; Wang, Q.; Zhong, Y.; Chang, Q.; Horner, J.W.; et al. Qki deficiency maintains stemness of glioma stem cells in suboptimal environment by downregulating endolysosomal degradation. Nat. Genet. 2017, 49, 75-86. [CrossRef]

97. Pillman, K.A.; Phillips, C.A.; Roslan, S.; Toubia, J.; Dredge, B.K.; Bert, A.G.; Lumb, R.; Neumann, D.P.; Li, X.; Conn, S.J.; et al. miR-200/375 control epithelial plasticity-associated alternative splicing by repressing the RNA-binding protein Quaking. EMBO J. 2018, 37. [CrossRef] 
98. Mukohyama, J.; Isobe, T.; Hu, Q.; Hayashi, T.; Watanabe, T.; Maeda, M.; Yanagi, H.; Qian, X.; Yamashita, K.; Minami, H.; et al. miR-221 Targets QKI to Enhance the Tumorigenic Capacity of Human Colorectal Cancer Stem Cells. Cancer Res. 2019, 79, 5151-5158. [CrossRef]

99. Li, P.; Yang, R.; Gao, W.Q. Contributions of epithelial-mesenchymal transition and cancer stem cells to the development of castration resistance of prostate cancer. Mol. Cancer 2014, 13, 55. [CrossRef]

100. Feldman, B.J.; Feldman, D. The development of androgen-independent prostate cancer. Nat. Rev. Cancer 2001, 1, 34-45. [CrossRef]

101. Li, L.; Xie, H.; Liang, L.; Gao, Y.; Zhang, D.; Fang, L.; Lee, S.O.; Luo, J.; Chen, X.; Wang, X.; et al. Increased PrLZ-mediated androgen receptor transactivation promotes prostate cancer growth at castration-resistant stage. Carcinogenesis 2013, 34, 257-267. [CrossRef]

102. Zeng, J.; Liu, W.; Fan, Y.Z.; He, D.L.; Li, L. PrLZ increases prostate cancer docetaxel resistance by inhibiting LKB1/AMPK-mediated autophagy. Theranostics 2018, 8, 109-123. [CrossRef] [PubMed]

103. Chen, W.; Liu, Y.; Chen, H.; Ning, H.; Ding, K. Loss of miR-449a-caused PrLZ overexpression promotes prostate cancer metastasis. Int. J. Oncol. 2017, 51, 435-444. [CrossRef] [PubMed]

104. Zhou, B.P.; Liao, Y.; Xia, W.; Spohn, B.; Lee, M.H.; Hung, M.C. Cytoplasmic localization of p21Cip1/WAF1 by Akt-induced phosphorylation in HER-2/neu-overexpressing cells. Nat Cell Biol. 2001, 3, 245-252. [CrossRef] [PubMed]

105. Chang, Y.L.; Zhou, P.J.; Wei, L.; Li, W.; Ji, Z.; Fang, Y.X.; Gao, W.Q. MicroRNA-7 inhibits the stemness of prostate cancer stem-like cells and tumorigenesis by repressing KLF4/PI3K/Akt/p21 pathway. Oncotarget 2015, 6, 24017-24031. [CrossRef] [PubMed]

106. Goel, G.; Sun, W. Advances in the management of gastrointestinal cancers-an upcoming role of immune checkpoint blockade. J. Hematol. Oncol. 2015, 8, 86. [CrossRef]

107. Digklia, A.; Wagner, A.D. Advanced gastric cancer: Current treatment landscape and future perspectives. World J. Gastroenterol. 2016, 22, 2403-2414. [CrossRef]

108. Jiang, L.; Li, J.; Song, L. Bmi-1, stem cells and cancer. Acta Biochim. Biophys. Sin. (Shanghai) 2009, 41, 527-534. [CrossRef]

109. Meng, F.; Henson, R.; Wehbe-Janek, H.; Ghoshal, K.; Jacob, S.T.; Patel, T. MicroRNA-21 regulates expression of the PTEN tumor suppressor gene in human hepatocellular cancer. Gastroenterology 2007, 133, 647-658. [CrossRef]

110. Papagiannakopoulos, T.; Shapiro, A.; Kosik, K.S. MicroRNA-21 targets a network of key tumor-suppressive pathways in glioblastoma cells. Cancer Res. 2008, 68, 8164-8172. [CrossRef]

111. Levine, A.J.; Puzio-Kuter, A.M.; Chan, C.S.; Hainaut, P. The Role of the p53 Protein in Stem-Cell Biology and Epigenetic Regulation. Cold Spring Harb. Perspect. Med. 2016, 6. [CrossRef] [PubMed]

112. Luongo, F.; Colonna, F.; Calapa, F.; Vitale, S.; Fiori, M.E.; De Maria, R. PTEN Tumor-Suppressor: The Dam of Stemness in Cancer. Cancers (Basel) 2019, 11. [CrossRef] [PubMed]

113. Zhang, Z.; Li, Z.; Gao, C.; Chen, P.; Chen, J.; Liu, W.; Xiao, S.; Lu, H. miR-21 plays a pivotal role in gastric cancer pathogenesis and progression. Lab. Investig. 2008, 88, 1358-1366. [CrossRef] [PubMed]

114. Fox, J.G.; Wang, T.C. Inflammation, atrophy, and gastric cancer. J. Clin. Investig 2007, 117, 60-69. [CrossRef] [PubMed]

115. Chang, J.T.; Wang, H.M.; Chang, K.W.; Chen, W.H.; Wen, M.C.; Hsu, Y.M.; Yung, B.Y.; Chen, I.H.; Liao, C.T.; Hsieh, L.L.; et al. Identification of differentially expressed genes in oral squamous cell carcinoma (OSCC): Overexpression of NPM, CDK1 and NDRG1 and underexpression of CHES1. Int. J. Cancer 2005, 114, 942-949. [CrossRef] [PubMed]

116. Sun, J.; Li, H.; Huo, Q.; Cui, M.; Ge, C.; Zhao, F.; Tian, H.; Chen, T.; Yao, M.; Li, J. The transcription factor FOXN3 inhibits cell proliferation by downregulating E2F5 expression in hepatocellular carcinoma cells. Oncotarget 2016, 7, 43534-43545. [CrossRef] [PubMed]

117. Han, T.S.; Voon, D.C.; Oshima, H.; Nakayama, M.; Echizen, K.; Sakai, E.; Yong, Z.W.E.; Murakami, K.; Yu, L.; Minamoto, T.; et al. Interleukin 1 Up-regulates MicroRNA 135b to Promote Inflammation-Associated Gastric Carcinogenesis in Mice. Gastroenterology 2019, 156. [CrossRef]

118. Ozturk, S.; Papageorgis, P.; Wong, C.K.; Lambert, A.W.; Abdolmaleky, H.M.; Thiagalingam, A.; Cohen, H.T.; Thiagalingam, S. SDPR functions as a metastasis suppressor in breast cancer by promoting apoptosis. Proc. Natl. Acad. Sci. USA 2016, 113, 638-643. [CrossRef] 
119. Luo, Y.; Wu, J.; Wu, Q.; Li, X.; Wu, J.; Zhang, J.; Rong, X.; Rao, J.; Liao, Y.; Bin, J.; et al. miR-577 Regulates TGF-beta Induced Cancer Progression through a SDPR-Modulated Positive-Feedback Loop with ERK-NF-kappaB in Gastric Cancer. Mol. Ther. 2019, 27, 1166-1182. [CrossRef]

120. Llovet, J.M.; Zucman-Rossi, J.; Pikarsky, E.; Sangro, B.; Schwartz, M.; Sherman, M.; Gores, G. Hepatocellular carcinoma. Nat. Rev. Dis. Primers 2016, 2, 16018. [CrossRef]

121. Kuldkepp, A.; Karakai, M.; Toomsoo, E.; Reinsalu, O.; Kurg, R. Cancer-testis antigens MAGEA proteins are incorporated into extracellular vesicles released by cells. Oncotarget 2019, 10, 3694-3708. [CrossRef] [PubMed]

122. Barrow, C.; Browning, J.; MacGregor, D.; Davis, I.D.; Sturrock, S.; Jungbluth, A.A.; Cebon, J. Tumor antigen expression in melanoma varies according to antigen and stage. Clin. Cancer Res. 2006, 12, 764-771. [CrossRef] [PubMed]

123. Hardie, D.G.; Ross, F.A.; Hawley, S.A. AMPK: A nutrient and energy sensor that maintains energy homeostasis. Nat Rev. Mol. Cell Biol. 2012, 13, 251-262. [CrossRef] [PubMed]

124. Guo, J.C.; Yang, Y.J.; Zhang, J.Q.; Guo, M.; Xiang, L.; Yu, S.F.; Ping, H.; Zhuo, L. microRNA-448 inhibits stemness maintenance and self-renewal of hepatocellular carcinoma stem cells through the MAGEA6-mediated AMPK signaling pathway. J. Cell. Physiol. 2019, 234, 23461-23474. [CrossRef]

125. Fan, R.; He, H.; Yao, W.; Zhu, Y.; Zhou, X.; Gui, M.; Lu, J.; Xi, H.; Deng, Z.; Fan, M. SOX7 Suppresses Wnt Signaling by Disrupting beta-Catenin/BCL9 Interaction. DNA Cell Biol. 2018, 37, 126-132. [CrossRef] [PubMed]

126. Zheng, Z.; Liu, J.; Yang, Z.; Wu, L.; Xie, H.; Jiang, C.; Lin, B.; Chen, T.; Xing, C.; Liu, Z.; et al. MicroRNA-452 promotes stem-like cells of hepatocellular carcinoma by inhibiting Sox7 involving Wnt/beta-catenin signaling pathway. Oncotarget 2016, 7, 28000-28012. [CrossRef]

127. Gong, Y.Q.; Peng, D.; Ning, X.H.; Yang, X.Y.; Li, X.S.; Zhou, L.Q.; Guo, Y.L. UBE2T silencing suppresses proliferation and induces cell cycle arrest and apoptosis in bladder cancer cells. Oncol. Lett. 2016, 12, 4485-4492. [CrossRef]

128. Perez-Pena, J.; Corrales-Sanchez, V.; Amir, E.; Pandiella, A.; Ocana, A. Ubiquitin-conjugating enzyme E2T (UBE2T) and denticleless protein homolog (DTL) are linked to poor outcome in breast and lung cancers. Sci. Rep. 2017, 7, 17530. [CrossRef]

129. Wei, X.; You, X.; Zhang, J.; Zhou, C. MicroRNA-1305 Inhibits the Stemness of LCSCs and Tumorigenesis by Repressing the UBE2T-Dependent Akt-Signaling Pathway. Mol. Ther. Nucleic Acids 2019, 16, 721-732. [CrossRef]

130. Sun, J.; Shi, R.; Zhao, S.; Li, X.; Lu, S.; Bu, H.; Ma, X.; Su, C. E2F8, a direct target of miR-144, promotes papillary thyroid cancer progression via regulating cell cycle. J. Exp. Clin. Cancer Res. 2017, 36, 40. [CrossRef]

131. Ma, Y.S.; Lv, Z.W.; Yu, F.; Chang, Z.Y.; Cong, X.L.; Zhong, X.M.; Lu, G.X.; Zhu, J.; Fu, D. MicroRNA-302a/d inhibits the self-renewal capability and cell cycle entry of liver cancer stem cells by targeting the E2F7/AKT axis. J. Exp. Clin. Cancer Res. 2018, 37, 252. [CrossRef] [PubMed]

132. Jiang, C.; Yu, M.; Xie, X.; Huang, G.; Peng, Y.; Ren, D.; Lin, M.; Liu, B.; Liu, M.; Wang, W.; et al. miR-217 targeting DKK1 promotes cancer stem cell properties via activation of the Wnt signaling pathway in hepatocellular carcinoma. Oncol. Rep. 2017, 38, 2351-2359. [CrossRef] [PubMed]

133. Wu, J.; Di, D.; Zhao, C.; Pan, Q.; Liu, Y.; Zhang, X.; Zhao, X.; Chen, H. Clinical Significance of Gli-1 And Caveolin-1 Expression in the Human Small Cell Lung Cancer. Asian Pac. J. Cancer Prev. 2018, 19, 401-406. [CrossRef] [PubMed]

134. Tremblay, M.L. On the role of tyrosine phosphatases as negative regulators of STAT signaling in breast cancers: New findings and future perspectives. Breast Cancer Res. 2013, 15, 312. [CrossRef]

135. Denu, J.M.; Dixon, J.E. Protein tyrosine phosphatases: Mechanisms of catalysis and regulation. Curr. Opin. Chem. Biol. 1998, 2, 633-641. [CrossRef]

136. Jiang, C.; Long, J.; Liu, B.; Xu, M.; Wang, W.; Xie, X.; Wang, X.; Kuang, M. miR-500a-3p promotes cancer stem cells properties via STAT3 pathway in human hepatocellular carcinoma. J. Exp. Clin. Cancer Res. 2017, 36, 99. [CrossRef]

137. Wang, J.; Rao, S.; Chu, J.; Shen, X.; Levasseur, D.N.; Theunissen, T.W.; Orkin, S.H. A protein interaction network for pluripotency of embryonic stem cells. Nature 2006, 444, 364-368. [CrossRef] 
138. Liu, Y.; Liu, D.L.; Dong, L.L.; Wen, D.; Shi, D.M.; Zhou, J.; Fan, J.; Wu, W.Z. miR-612 suppresses stem cell-like property of hepatocellular carcinoma cells by modulating Sp1/Nanog signaling. Cell Death Dis. 2016, 7, e2377. [CrossRef]

139. Kang, X.; Kong, F.; Wu, S.; Liu, Q.; Yang, C.; Wu, X.; Zhang, W. microRNA-612 suppresses the malignant development of non-small-cell lung cancer by directly targeting bromodomain-containing protein 4 . Onco Targets Ther. 2019, 12, 4167-4179. [CrossRef]

140. Wang, L.; Bo, X.; Zheng, Q.; Ge, W.; Liu, Y.; Li, B. Paired box 8 suppresses tumor angiogenesis and metastasis in gastric cancer through repression of FOXM1 via induction of microRNA-612. J. Exp. Clin. Cancer Res. 2018, 37, 159. [CrossRef]

141. Yu, H.; Xu, Y.; Zhang, D.; Liu, G. Long noncoding RNA LUCAT1 promotes malignancy of ovarian cancer through regulation of miR-612/HOXA13 pathway. Biochem. Biophys. Res. Commun. 2018, 503, 2095-2100. [CrossRef] [PubMed]

142. Lu, S.C.; Mato, J.M. S-Adenosylmethionine in cell growth, apoptosis and liver cancer. J. Gastroenterol. Hepatol. 2008, 23 (Suppl. S1), S73-S77. [CrossRef]

143. Frau, M.; Tomasi, M.L.; Simile, M.M.; Demartis, M.I.; Salis, F.; Latte, G.; Calvisi, D.F.; Seddaiu, M.A.; Daino, L.; Feo, C.F.; et al. Role of transcriptional and posttranscriptional regulation of methionine adenosyltransferases in liver cancer progression. Hepatology 2012, 56, 165-175. [CrossRef] [PubMed]

144. Mato, J.M.; Lu, S.C. Role of S-adenosyl-L-methionine in liver health and injury. Hepatology 2007, 45, $1306-1312$. [CrossRef] [PubMed]

145. Hwang, J.M.; Kuo, H.C.; Tseng, T.H.; Liu, J.Y.; Chu, C.Y. Berberine induces apoptosis through a mitochondria/caspases pathway in human hepatoma cells. Arch. Toxicol. 2006, 80, 62-73. [CrossRef] [PubMed]

146. Ma, C.; Tang, K.; Liu, Q.; Zhu, R.; Cao, Z. Calmodulin as a potential target by which berberine induces cell cycle arrest in human hepatoma Bel7402 cells. Chem. Biol. Drug Des. 2013, 81, 775-783. [CrossRef] [PubMed]

147. Wang, N.; Feng, Y.; Zhu, M.; Tsang, C.M.; Man, K.; Tong, Y.; Tsao, S.W. Berberine induces autophagic cell death and mitochondrial apoptosis in liver cancer cells: The cellular mechanism. J. Cell. Biochem. 2010, 111, 1426-1436. [CrossRef]

148. Lo, T.F.; Tsai, W.C.; Chen, S.T. MicroRNA-21-3p, a berberine-induced miRNA, directly down-regulates human methionine adenosyltransferases 2A and 2B and inhibits hepatoma cell growth. PLoS ONE 2013, 8, e75628. [CrossRef]

149. Janmaat, V.T.; Steyerberg, E.W.; van der Gaast, A.; Mathijssen, R.H.; Bruno, M.J.; Peppelenbosch, M.P.; Kuipers, E.J.; Spaander, M.C. Palliative chemotherapy and targeted therapies for esophageal and gastroesophageal junction cancer. Cochrane Database Syst. Rev. 2017, 11, CD004063. [CrossRef]

150. Li, X.; Qiao, Y.; Chang, L.S.; Xiao, F.; Lu, L.H.; Hao, X.H.; Zhang, R.W.; Wu, H.; Wei, H.S. Role of C6ORF120, an N-glycosylated protein, is implicated in apoptosis of CD4(+) T lymphocytes. Chin. Med. J. (Engl.) 2011, $124,3560-3567$.

151. Lynam-Lennon, N.; Heavey, S.; Sommerville, G.; Bibby, B.A.; Ffrench, B.; Quinn, J.; Gasch, C.; O’Leary, J.J.; Gallagher, M.F.; Reynolds, J.V.; et al. MicroRNA-17 is downregulated in esophageal adenocarcinoma cancer stem-like cells and promotes a radioresistant phenotype. Oncotarget 2017, 8, 11400-11413. [CrossRef] [PubMed]

152. Bergmann, K.; Sypniewska, G. Secreted frizzled-related protein 4 (SFRP4) and fractalkine (CX3CL1) Potential new biomarkers for beta-cell dysfunction and diabetes. Clin. Biochem. 2014, 47, 529-532. [CrossRef] [PubMed]

153. Clevers, H.; Nusse, R. Wnt/beta-catenin signaling and disease. Cell 2012, 149, 1192-1205. [CrossRef] [PubMed]

154. Chodaparambil, J.V.; Pate, K.T.; Hepler, M.R.; Tsai, B.P.; Muthurajan, U.M.; Luger, K.; Waterman, M.L.; Weis, W.I. Molecular functions of the TLE tetramerization domain in Wnt target gene repression. EMBO J. 2014, 33, 719-731. [CrossRef] [PubMed]

155. Ge, C.; Wu, S.; Wang, W.; Liu, Z.; Zhang, J.; Wang, Z.; Li, R.; Zhang, Z.; Li, Z.; Dong, S.; et al. miR-942 promotes cancer stem cell-like traits in esophageal squamous cell carcinoma through activation of Wnt/beta-catenin signalling pathway. Oncotarget 2015, 6, 10964-10977. [CrossRef] 
156. Ye, X.; Mehlen, P.; Rabizadeh, S.; VanArsdale, T.; Zhang, H.; Shin, H.; Wang, J.J.; Leo, E.; Zapata, J.; Hauser, C.A.; et al. TRAF family proteins interact with the common neurotrophin receptor and modulate apoptosis induction. J. Biol. Chem. 1999, 274, 30202-30208. [CrossRef]

157. Gao, Z.; Liu, H.; Shi, Y.; Yin, L.; Zhu, Y.; Liu, R. Identification of Cancer Stem Cell Molecular Markers and Effects of hsa-miR-21-3p on Stemness in Esophageal Squamous Cell Carcinoma. Cancers (Basel) 2019, 11. [CrossRef]

158. Akhtar-Danesh, G.G.; Finley, C.; Akhtar-Danesh, N. Long-term trends in the incidence and relative survival of pancreatic cancer in Canada: A population-based study. Pancreatology 2016, 16, 259-265. [CrossRef]

159. He, Z.; Guo, X.; Tian, S.; Zhu, C.; Chen, S.; Yu, C.; Jiang, J.; Sun, C. MicroRNA-137 reduces stemness features of pancreatic cancer cells by targeting KLF12. J. Exp. Clin. Cancer Res. 2019, 38, 126. [CrossRef]

160. Zhao, M.; Amiel, S.A.; Christie, M.R.; Muiesan, P.; Srinivasan, P.; Littlejohn, W.; Rela, M.; Arno, M.; Heaton, N.; Huang, G.C. Evidence for the presence of stem cell-like progenitor cells in human adult pancreas. J. Endocrinol. 2007, 195, 407-414. [CrossRef]

161. Herreros-Villanueva, M.; Zhang, J.S.; Koenig, A.; Abel, E.V.; Smyrk, T.C.; Bamlet, W.R.; de Narvajas, A.A.; Gomez, T.S.; Simeone, D.M.; Bujanda, L.; et al. SOX2 promotes dedifferentiation and imparts stem cell-like features to pancreatic cancer cells. Oncogenesis 2013, 2, e61. [CrossRef] [PubMed]

162. Kostromina, E.; Gustavsson, N.; Wang, X.; Lim, C.Y.; Radda, G.K.; Li, C.; Han, W. Glucose intolerance and impaired insulin secretion in pancreas-specific signal transducer and activator of transcription-3 knockout mice are associated with microvascular alterations in the pancreas. Endocrinology 2010, 151, 2050-2059. [CrossRef] [PubMed]

163. Fukuda, A.; Wang, S.C.; Morris, J.P.t.; Folias, A.E.; Liou, A.; Kim, G.E.; Akira, S.; Boucher, K.M.; Firpo, M.A.; Mulvihill, S.J.; et al. Stat3 and MMP7 contribute to pancreatic ductal adenocarcinoma initiation and progression. Cancer Cell 2011, 19, 441-455. [CrossRef] [PubMed]

164. Jiang, J.; Li, Z.; Yu, C.; Chen, M.; Tian, S.; Sun, C. MiR-1181 inhibits stem cell-like phenotypes and suppresses SOX2 and STAT3 in human pancreatic cancer. Cancer Lett. 2015, 356, 962-970. [CrossRef]

165. Tsukasa, K.; Ding, Q.; Miyazaki, Y.; Matsubara, S.; Natsugoe, S.; Takao, S. miR-30 family promotes migratory and invasive abilities in CD133(+) pancreatic cancer stem-like cells. Hum. Cell 2016, 29, 130-137. [CrossRef] [PubMed]

166. Li, M.; Lee, K.F.; Lu, Y.; Clarke, I.; Shih, D.; Eberhart, C.; Collins, V.P.; Van Meter, T.; Picard, D.; Zhou, L.; et al. Frequent amplification of a chr19q13.41 microRNA polycistron in aggressive primitive neuroectodermal brain tumors. Cancer Cell 2009, 16, 533-546. [CrossRef]

167. Bortolin-Cavaille, M.L.; Dance, M.; Weber, M.; Cavaille, J. C19MC microRNAs are processed from introns of large Pol-II, non-protein-coding transcripts. Nucleic Acids Res. 2009, 37, 3464-3473. [CrossRef]

168. Wu, H.N.; Cao, X.L.; Fang, Z.; Zhang, Y.F.; Han, W.J.; Yue, K.Y.; Cao, Y.; Zheng, M.H.; Wang, L.L.; Han, H. Deficiency of Ttyh1 downstream to Notch signaling results in precocious differentiation of neural stem cells. Biochem. Biophys. Res. Commun. 2019, 514, 842-847. [CrossRef]

169. Kleinman, C.L.; Gerges, N.; Papillon-Cavanagh, S.; Sin-Chan, P.; Pramatarova, A.; Quang, D.A.; Adoue, V.; Busche, S.; Caron, M.; Djambazian, H.; et al. Fusion of TTYH1 with the C19MC microRNA cluster drives expression of a brain-specific DNMT3B isoform in the embryonal brain tumor ETMR. Nat. Genet. 2014, 46, 39-44. [CrossRef]

170. Sin-Chan, P.; Mumal, I.; Suwal, T.; Ho, B.; Fan, X.; Singh, I.; Du, Y.; Lu, M.; Patel, N.; Torchia, J.; et al. A C19MC-LIN28A-MYCN Oncogenic Circuit Driven by Hijacked Super-enhancers Is a Distinct Therapeutic Vulnerability in ETMRs: A Lethal Brain Tumor. Cancer Cell 2019, 36. [CrossRef]

171. Gopalakrishna-Pillai, S.; Iverson, L.E. A DNMT3B alternatively spliced exon and encoded peptide are novel biomarkers of human pluripotent stem cells. PLoS ONE 2011, 6, e20663. [CrossRef] [PubMed]

172. Hayette, S.; Thomas, X.; Jallades, L.; Chabane, K.; Charlot, C.; Tigaud, I.; Gazzo, S.; Morisset, S.; Cornillet-Lefebvre, P.; Plesa, A.; et al. High DNA methyltransferase DNMT3B levels: A poor prognostic marker in acute myeloid leukemia. PLoS ONE 2012, 7, e51527. [CrossRef] [PubMed]

173. Flor, I.; Spiekermann, M.; Loning, T.; Dieckmann, K.P.; Belge, G.; Bullerdiek, J. Expression of microRNAs of C19MC in Different Histological Types of Testicular Germ Cell Tumour. Cancer Genom. Proteom. 2016, 13, 281-289. 
174. Verdelli, C.; Forno, I.; Morotti, A.; Creo, P.; Guarnieri, V.; Scillitani, A.; Cetani, F.; Vicentini, L.; Balza, G.; Beretta, E.; et al. The aberrantly expressed miR-372 partly impairs sensitivity to apoptosis in parathyroid tumor cells. Endocr. Relat. Cancer 2018, 25, 761-771. [CrossRef]

175. Oeztuerk-Winder, F.; Guinot, A.; Ochalek, A.; Ventura, J.J. Regulation of human lung alveolar multipotent cells by a novel p38alpha MAPK/miR-17-92 axis. EMBO J. 2012, 31, 3431-3441. [CrossRef]

176. Osada, H.; Takahashi, T. let-7 and miR-17-92: Small-sized major players in lung cancer development. Cancer Sci. 2011, 102, 9-17. [CrossRef]

177. Guinot, A.; Oeztuerk-Winder, F.; Ventura, J.J. miR-17-92/p38alpha Dysregulation Enhances Wnt Signaling and Selects Lgr6+ Cancer Stem-like Cells during Lung Adenocarcinoma Progression. Cancer Res. 2016, 76, 4012-4022. [CrossRef]

178. Zagorac, S.; Alcala, S.; Fernandez Bayon, G.; Bou Kheir, T.; Schoenhals, M.; Gonzalez-Neira, A.; Fernandez Fraga, M.; Aicher, A.; Heeschen, C.; Sainz, B., Jr. DNMT1 Inhibition Reprograms Pancreatic Cancer Stem Cells via Upregulation of the miR-17-92 Cluster. Cancer Res. 2016, 76, 4546-4558. [CrossRef]

179. Faversani, A.; Amatori, S.; Augello, C.; Colombo, F.; Porretti, L.; Fanelli, M.; Ferrero, S.; Palleschi, A.; Pelicci, P.G.; Belloni, E.; et al. miR-494-3p is a novel tumor driver of lung carcinogenesis. Oncotarget 2017, 8, 7231-7247. [CrossRef]

180. Lehner, B.; Kunz, P.; Saehr, H.; Fellenberg, J. Epigenetic silencing of genes and microRNAs within the imprinted Dlk1-Dio3 region at human chromosome 14.32 in giant cell tumor of bone. BMC Cancer 2014, 14, 495. [CrossRef]

181. Nguyen, P.N.; Huang, C.J.; Sugii, S.; Cheong, S.K.; Choo, K.B. Selective activation of miRNAs of the primate-specific chromosome 19 miRNA cluster (C19MC) in cancer and stem cells and possible contribution to regulation of apoptosis. J. Biomed. Sci. 2017, 24, 20. [CrossRef] [PubMed]

182. Augello, C.; Colombo, F.; Terrasi, A.; Trombetta, E.; Maggioni, M.; Porretti, L.; Rossi, G.; Guerneri, S.; Silipigni, R.; Bosari, S.; et al. Expression of C19MC miRNAs in HCC associates with stem-cell features and the cancer-testis genes signature. Dig. Liver Dis. 2018, 50, 583-593. [CrossRef] [PubMed]

183. Ma, W.; Yu, Q.; Jiang, J.; Du, X.; Huang, L.; Zhao, L.; Zhou, Q.I. miR-517a is an independent prognostic marker and contributes to cell migration and invasion in human colorectal cancer. Oncol. Lett. 2016, 11, 2583-2589. [CrossRef] [PubMed]

184. Augello, C.; Vaira, V.; Caruso, L.; Destro, A.; Maggioni, M.; Park, Y.N.; Montorsi, M.; Santambrogio, R.; Roncalli, M.; Bosari, S. MicroRNA profiling of hepatocarcinogenesis identifies C19MC cluster as a novel prognostic biomarker in hepatocellular carcinoma. Liver Int. 2012, 32, 772-782. [CrossRef]

185. Rippe, V.; Dittberner, L.; Lorenz, V.N.; Drieschner, N.; Nimzyk, R.; Sendt, W.; Junker, K.; Belge, G.; Bullerdiek, J. The two stem cell microRNA gene clusters C19MC and miR-371-3 are activated by specific chromosomal rearrangements in a subgroup of thyroid adenomas. PLoS ONE 2010, 5, e9485. [CrossRef]

186. Smith, B.; Agarwal, P.; Bhowmick, N.A. MicroRNA applications for prostate, ovarian and breast cancer in the era of precision medicine. Endocr. Relat. Cancer 2017, 24, R157-R172. [CrossRef]

187. Wienholds, E.; Kloosterman, W.P.; Miska, E.; Alvarez-Saavedra, E.; Berezikov, E.; de Bruijn, E.; Horvitz, H.R.; Kauppinen, S.; Plasterk, R.H. MicroRNA expression in zebrafish embryonic development. Science 2005, 309, 310-311. [CrossRef]

188. Kontomanolis, E.N.; Kalagasidou, S.; Fasoulakis, Z. MicroRNAs as Potential Serum Biomarkers for Early Detection of Ectopic Pregnancy. Cureus 2018, 10, e2344. [CrossRef]

189. Hanahan, D.; Weinberg, R.A. Hallmarks of cancer: The next generation. Cell 2011, 144, 646-674. [CrossRef]

190. Rodriguez-Aznar, E.; Wiesmuller, L.; Sainz, B., Jr.; Hermann, P.C. EMT and Stemness-Key Players in Pancreatic Cancer Stem Cells. Cancers (Basel) 2019, 11. [CrossRef]

191. Lang, M.F.; Yang, S.; Zhao, C.; Sun, G.; Murai, K.; Wu, X.; Wang, J.; Gao, H.; Brown, C.E.; Liu, X.; et al. Genome-wide profiling identified a set of miRNAs that are differentially expressed in glioblastoma stem cells and normal neural stem cells. PLoS ONE 2012, 7, e36248. [CrossRef] [PubMed]

192. Delaloy, C.; Gao, F.B. A new role for microRNA-9 in human neural progenitor cells. Cell Cycle 2010, 9, 2913-2914. [CrossRef] [PubMed]

193. Delaloy, C.; Liu, L.; Lee, J.A.; Su, H.; Shen, F.; Yang, G.Y.; Young, W.L.; Ivey, K.N.; Gao, F.B. MicroRNA-9 coordinates proliferation and migration of human embryonic stem cell-derived neural progenitors. Cell Stem Cell 2010, 6, 323-335. [CrossRef] 
194. Jeon, H.M.; Sohn, Y.W.; Oh, S.Y.; Kim, S.H.; Beck, S.; Kim, S.; Kim, H. ID4 imparts chemoresistance and cancer stemness to glioma cells by derepressing miR-9*-mediated suppression of SOX2. Cancer Res. 2011, 71, 3410-3421. [CrossRef] [PubMed]

195. Jonsson, M.E.; Nelander Wahlestedt, J.; Akerblom, M.; Kirkeby, A.; Malmevik, J.; Brattaas, P.L.; Jakobsson, J.; Parmar, M. Comprehensive analysis of microRNA expression in regionalized human neural progenitor cells reveals microRNA-10 as a caudalizing factor. Development 2015, 142, 3166-3177. [CrossRef]

196. Gabriely, G.; Yi, M.; Narayan, R.S.; Niers, J.M.; Wurdinger, T.; Imitola, J.; Ligon, K.L.; Kesari, S.; Esau, C.; Stephens, R.M.; et al. Human glioma growth is controlled by microRNA-10b. Cancer Res. 2011, 71, 3563-3572. [CrossRef]

197. Guessous, F.; Alvarado-Velez, M.; Marcinkiewicz, L.; Zhang, Y.; Kim, J.; Heister, S.; Kefas, B.; Godlewski, J.; Schiff, D.; Purow, B.; et al. Oncogenic effects of miR-10b in glioblastoma stem cells. J. Neurooncol. 2013, 112, 153-163. [CrossRef]

198. Teplyuk, N.M.; Uhlmann, E.J.; Gabriely, G.; Volfovsky, N.; Wang, Y.; Teng, J.; Karmali, P.; Marcusson, E.; Peter, M.; Mohan, A.; et al. Therapeutic potential of targeting microRNA-10b in established intracranial glioblastoma: First steps toward the clinic. EMBO Mol. Med. 2016, 8, 268-287. [CrossRef]

199. Rolle, K. miRNA Multiplayers in glioma. From bench to bedside. Acta Biochim Pol. 2015, 62, $353-365$. [CrossRef]

200. Boissart, C.; Nissan, X.; Giraud-Triboult, K.; Peschanski, M.; Benchoua, A. miR-125 potentiates early neural specification of human embryonic stem cells. Development 2012, 139, 1247-1257. [CrossRef]

201. Lagos-Quintana, M.; Rauhut, R.; Yalcin, A.; Meyer, J.; Lendeckel, W.; Tuschl, T. Identification of tissue-specific microRNAs from mouse. Curr. Biol. 2002, 12, 735-739. [CrossRef]

202. Silber, J.; Hashizume, R.; Felix, T.; Hariono, S.; Yu, M.; Berger, M.S.; Huse, J.T.; VandenBerg, S.R.; James, C.D.; Hodgson, J.G.; et al. Expression of miR-124 inhibits growth of medulloblastoma cells. Neuro Oncol. 2013, 15, 83-90. [CrossRef] [PubMed]

203. Liu, S.; Yin, F.; Zhang, J.; Wicha, M.S.; Chang, A.E.; Fan, W.; Chen, L.; Fan, M.; Li, Q. Regulatory roles of miRNA in the human neural stem cell transformation to glioma stem cells. J. Cell. Biochem. 2014, 115, 1368-1380. [CrossRef] [PubMed]

204. Rich, J.N. Cancer stem cells: Understanding tumor hierarchy and heterogeneity. Medicine (Baltimore) 2016, 95, S2-S7. [CrossRef] [PubMed]

205. Hezroni, H.; Koppstein, D.; Schwartz, M.G.; Avrutin, A.; Bartel, D.P.; Ulitsky, I. Principles of long noncoding RNA evolution derived from direct comparison of transcriptomes in 17 species. Cell Rep. 2015, 11, 1110-1122. [CrossRef] [PubMed]

206. Ye, F.; Tian, L.; Zhou, Q.; Feng, D. LncRNA FER1L4 induces apoptosis and suppresses EMT and the activation of PI3K/AKT pathway in osteosarcoma cells via inhibiting miR-18a-5p to promote SOCS5. Gene 2019, 721, 144093. [CrossRef]

207. Guo, X.; Jing, Y.M.; Lou, H.Z.; Lou, Q.A. Effect and mechanism of long non-coding RNA ZEB2-AS1 in the occurrence and development of colon cancer. Math. Biosci. Eng. 2019, 16, 8109-8120. [CrossRef]

208. Beltran, M.; Puig, I.; Pena, C.; Garcia, J.M.; Alvarez, A.B.; Pena, R.; Bonilla, F.; de Herreros, A.G. A natural antisense transcript regulates Zeb2/Sip1 gene expression during Snail1-induced epithelial-mesenchymal transition. Genes Dev. 2008, 22, 756-769. [CrossRef]

209. Yu, Y.; Li, L.; Zheng, Z.; Chen, S.; Chen, E.; Hu, Y. Long non-coding RNA linc00261 suppresses gastric cancer progression via promoting Slug degradation. J. Cell. Mol. Med. 2017, 21, 955-967. [CrossRef]

210. Place, R.F.; Li, L.C.; Pookot, D.; Noonan, E.J.; Dahiya, R. MicroRNA-373 induces expression of genes with complementary promoter sequences. Proc. Natl. Acad. Sci. USA 2008, 105, 1608-1613. [CrossRef]

211. Neelamraju, Y.; Gonzalez-Perez, A.; Bhat-Nakshatri, P.; Nakshatri, H.; Janga, S.C. Mutational landscape of RNA-binding proteins in human cancers. RNA Biol. 2018, 15, 115-129. [CrossRef]

212. Chiou, G.Y.; Yang, T.W.; Huang, C.C.; Tang, C.Y.; Yen, J.Y.; Tsai, M.C.; Chen, H.Y.; Fadhilah, N.; Lin, C.C.; Jong, Y.J. Musashi-1 promotes a cancer stem cell lineage and chemoresistance in colorectal cancer cells. Sci. Rep. 2017, 7, 2172. [CrossRef] [PubMed]

213. Lin, J.C.; Tsai, J.T.; Chao, T.Y.; Ma, H.I.; Chien, C.S.; Liu, W.H. MSI1 associates glioblastoma radioresistance via homologous recombination repair, tumor invasion and cancer stem-like cell properties. Radiother. Oncol. 2018, 129, 352-363. [CrossRef] 
214. Sureban, S.M.; Qu, D.; Houchen, C.W. Regulation of miRNAs by agents targeting the tumor stem cell markers DCLK1, MSI1, LGR5, and BMI1. Curr. Pharmacol. Rep. 2015, 1, 217-222. [CrossRef] [PubMed]

215. Imai, T.; Tokunaga, A.; Yoshida, T.; Hashimoto, M.; Mikoshiba, K.; Weinmaster, G.; Nakafuku, M.; Okano, H. The neural RNA-binding protein Musashi1 translationally regulates mammalian numb gene expression by interacting with its mRNA. Mol. Cell. Biol. 2001, 21, 3888-3900. [CrossRef] [PubMed]

216. Katz, Y.; Li, F.; Lambert, N.J.; Sokol, E.S.; Tam, W.L.; Cheng, A.W.; Airoldi, E.M.; Lengner, C.J.; Gupta, P.B.; $\mathrm{Yu}, \mathrm{Z}$.; et al. Musashi proteins are post-transcriptional regulators of the epithelial-luminal cell state. eLife 2014, 3, e03915. [CrossRef]

217. Yang, Y.; Hsu, P.J.; Chen, Y.S.; Yang, Y.G. Dynamic transcriptomic m(6)A decoration: Writers, erasers, readers and functions in RNA metabolism. Cell Res. 2018, 28, 616-624. [CrossRef] [PubMed]

218. Cui, Q.; Shi, H.; Ye, P.; Li, L.; Qu, Q.; Sun, G.; Sun, G.; Lu, Z.; Huang, Y.; Yang, C.G.; et al. m(6)A RNA Methylation Regulates the Self-Renewal and Tumorigenesis of Glioblastoma Stem Cells. Cell Rep. 2017, 18, 2622-2634. [CrossRef]

219. Sun, Y.; Ding, L.; Zhang, H.; Han, J.; Yang, X.; Yan, J.; Zhu, Y.; Li, J.; Song, H.; Ye, Q. Potentiation of Smad-mediated transcriptional activation by the RNA-binding protein RBPMS. Nucleic Acids Res. 2006, 34, 6314-6326. [CrossRef]

220. Parker, H.; Rose-Zerilli, M.J.; Parker, A.; Chaplin, T.; Wade, R.; Gardiner, A.; Griffiths, M.; Collins, A.; Young, B.D.; Oscier, D.G.; et al. 13q deletion anatomy and disease progression in patients with chronic lymphocytic leukemia. Leukemia 2011, 25, 489-497. [CrossRef]

221. Yang, S.; Chen, J.; Guo, Y.; Lin, H.; Zhang, Z.; Feng, G.; Hao, Y.; Cheng, J.; Liang, P.; Chen, K.; et al. Identification of prognostic biomarkers for response to radiotherapy by DNA microarray in nasopharyngeal carcinoma patients. Int. J. Oncol. 2012, 40, 1590-1600. [CrossRef] [PubMed]

222. Baez-Vega, P.M.; Echevarria Vargas, I.M.; Valiyeva, F.; Encarnacion-Rosado, J.; Roman, A.; Flores, J.; Marcos-Martinez, M.J.; Vivas-Mejia, P.E. Targeting miR-21-3p inhibits proliferation and invasion of ovarian cancer cells. Oncotarget 2016, 7, 36321-36337. [CrossRef] [PubMed]

223. Wang, W.; Li, Y.; Liu, N.; Gao, Y.; Li, L. MiR-23b controls ALDH1A1 expression in cervical cancer stem cells. BMC Cancer 2017, 17, 292. [CrossRef] [PubMed]

224. Ginestier, C.; Hur, M.H.; Charafe-Jauffret, E.; Monville, F.; Dutcher, J.; Brown, M.; Jacquemier, J.; Viens, P.; Kleer, C.G.; Liu, S.; et al. ALDH1 is a marker of normal and malignant human mammary stem cells and a predictor of poor clinical outcome. Cell Stem Cell 2007, 1, 555-567. [CrossRef] [PubMed]

225. Luo, H.; Yang, R.; Li, C.; Tong, Y.; Fan, L.; Liu, X.; Xu, C. MicroRNA-139-5p inhibits bladder cancer proliferation and self-renewal by targeting the Bmi1 oncogene. Tumour Biol. 2017, 39, 1010428317718414. [CrossRef] [PubMed]

226. Nita, M.E.; Nagawa, H.; Tominaga, O.; Tsuno, N.; Fujii, S.; Sasaki, S.; Fu, C.G.; Takenoue, T.; Tsuruo, T.; Muto, T. 5-Fluorouracil induces apoptosis in human colon cancer cell lines with modulation of Bcl-2 family proteins. Br. J. Cancer 1998, 78, 986-992. [CrossRef]

227. Sax, J.K.; El-Deiry, W.S. Identification and characterization of the cytoplasmic protein TRAF4 as a p53-regulated proapoptotic gene. J. Biol. Chem. 2003, 278, 36435-36444. [CrossRef]

228. Li, X.; Lewis, M.T.; Huang, J.; Gutierrez, C.; Osborne, C.K.; Wu, M.F.; Hilsenbeck, S.G.; Pavlick, A.; Zhang, X.; Chamness, G.C.; et al. Intrinsic resistance of tumorigenic breast cancer cells to chemotherapy. J. Natl. Cancer Inst 2008, 100, 672-679. [CrossRef]

229. Ha, H.T.; Griffith, K.A.; Zalupski, M.M.; Schuetze, S.M.; Thomas, D.G.; Lucas, D.R.; Baker, L.H.; Chugh, R. Phase II trial of cetuximab in patients with metastatic or locally advanced soft tissue or bone sarcoma. Am. J. Clin. Oncol. 2013, 36, 77-82. [CrossRef]

230. Rosell, R.; Carcereny, E.; Gervais, R.; Vergnenegre, A.; Massuti, B.; Felip, E.; Palmero, R.; Garcia-Gomez, R.; Pallares, C.; Sanchez, J.M.; et al. Erlotinib versus standard chemotherapy as first-line treatment for European patients with advanced EGFR mutation-positive non-small-cell lung cancer (EURTAC): A multicentre, open-label, randomised phase 3 trial. Lancet Oncol. 2012, 13, 239-246. [CrossRef]

231. Yao, J.C.; Phan, A.T.; Jehl, V.; Shah, G.; Meric-Bernstam, F. Everolimus in advanced pancreatic neuroendocrine tumors: The clinical experience. Cancer Res. 2013, 73, 1449-1453. [CrossRef] [PubMed] 
232. Prokopi, M.; Kousparou, C.A.; Epenetos, A.A. The Secret Role of microRNAs in Cancer Stem Cell Development and Potential Therapy: A Notch-Pathway Approach. Front. Oncol. 2014, 4, 389. [CrossRef] [PubMed]

233. O'Day, E.; Lal, A. MicroRNAs and their target gene networks in breast cancer. Breast Cancer Res. 2010, $12,201$. [CrossRef] [PubMed]

(c) (C) 2019 by the authors. Licensee MDPI, Basel, Switzerland. This article is an open access article distributed under the terms and conditions of the Creative Commons Attribution (CC BY) license (http://creativecommons.org/licenses/by/4.0/). 